AMERICAN DAIRYING.

\title{
МОЛОЧНОЕ ДБЛО.
}

$\mathrm{Bb}$

\author{
СОЕДИНЕННЫХЪ ШТАТАХЪ
}

\section{ПО АМЕРИКАНСКИМЪ ИСТОЧНИКАМЪ}

С О с т в и л в

C. В. Гейман в.

\author{
И 3 А В 10 \\ МЕЖДЈНАРОДНАГО КНИГОИЗДАТЕЛЬСТВА \\ Нью IOРКЂ
}

International Book Publishing Company

5 Beekman Street

Teleph. Cortlandt 2949.

\begin{abstract}
NEW YORK, N. Y.
\end{abstract}




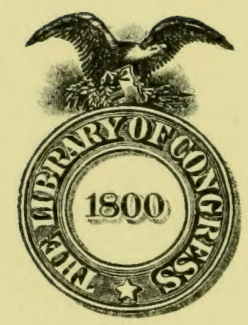

Class

Book

YUDIN COLLECTION

APO 





\section{ПОПУЛЯРНО - НАУЧНАЯ БИБЛІОТЕКА}

ПОДЪ РЕА. ПРОФ. Н. А. БОРОДИНА.

№ 8.

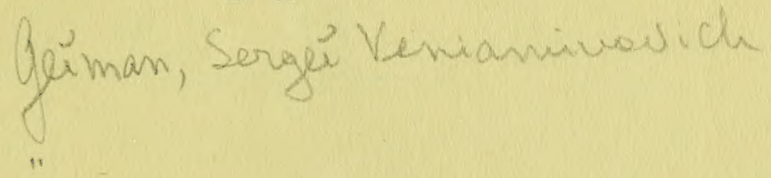

\section{CЕРГЪЙ ГЕЙМАНъ.}

\section{МОЛОЧНОЕ ДЪЛО}

ВЪ СОЕДИНЕННЫХЪ ШТАТАХЪ СЬВЕРНОЙ АМЕРИКИ

\section{tos}

МЕЖДУНАРОДНОЕ КНИГОИЗДАТЕЛЬСТВО

Нью-Іоркъ

1920 


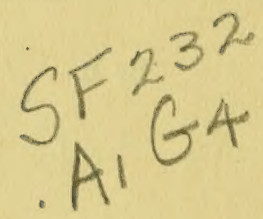

Copyright, 1920

By

International Book Publishing Company. 


\section{ОГЛАВЛ ЕН I E.}

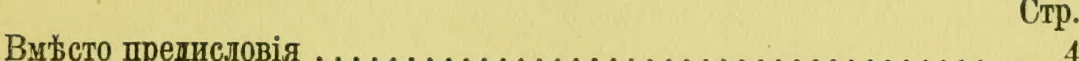

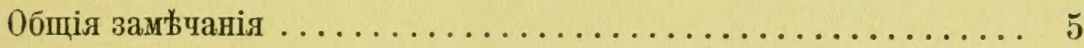

Проблема молочнаго дъ.ла..................... 11

Санитарныя условія производства................. 13

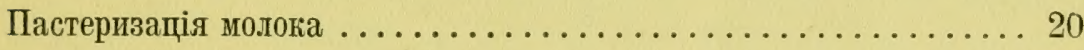

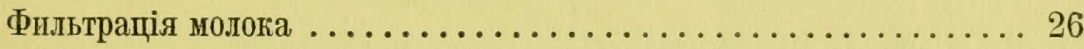

Захолаживаніе молока ............................ 29

Классификація молока ....................... 33

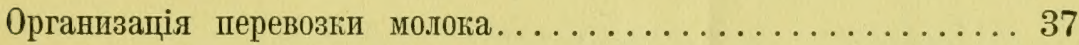

Выборъ молочнаго скота........................ 41

Статистика молочнаго скота.................... 44

Экономическіе факторы молочнаго хозяйства........... 47

Организація сбыта молока........................ 59

Лига молочно-фермерскихъ органивацій. . . . . . . . . . 64

Снабженіе молокомъ т. Нью-Іорка. . . . . . . . . . . . . . . 69

Пронзводетво сухого молока................... 73

Приложеніе І. Библіограбія.................... 78

“ II. Фермерскіе кооперативы по сбыту молока...... 84

“ III. Діаграмма роста цйнъ на молоко......... 87 



\section{ВМちСТО ПРЕДИСЛОВІЯ.}

По своияъ природным'ь условіямь Соединенные Штаты Съверной Амернки во многомъ напоминають Россію.

Намъ, русскимъ, предстоить большая созидательная работа у себя на родинь. И къ этой работь мы должны быть готовы. Поэтому пзученіе промьшленности, торговли, финансовъ, новЊйпихъ методовт пронзводства и организаціи американцевъ полезно и для предстояпей работы необходимо.

Вотъ почему мы съ удовольствіемъ реконендуемъ очеркъ С. Гей-

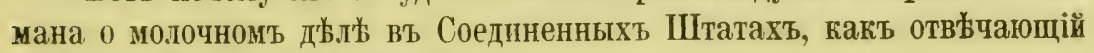
отмичченной выше потребности.

Уполномоченный Союза Спбирскихъ Маслодъьльныхъ Артелей Владиміръ Башкировъ.

Нью-Іорвъ, 16 января $1920 \mathrm{r}$. 



\section{0 Т 3 b B b.}

Предлагаемал впиманію чштателей брошюра г. С. Гейжана „М0лочное Хозяйство въ Соединенныхъ НІтатахъ Съверной Амернии" представляеть собой достаточно пол̈ную сводку данныхъ 0 состояніи молочнаго хозяйства въ современной Америкъ и харантеристику методовт, его веденія.

Система снабженіл крупныхъ городскихъ центровъ молочными продуктами вт колоссальномь масштабъ; методы улучшенія качества молока въ смыслћ, съ одної стороны, питательності его, а с другойполнаго обезвреживанія этого важжнаго продукта отъ инфекціонныхъ началь; созданіе мопнаго работаюпаго механизма распредъ.ленія м0лока: напряженная работа въ этпхъ направленіяхъ органовъ городского самоуправленія Іг общественныхт организацій, наконецъ, такъ сказать, обпественная „молочная “ санитарная,--все это освъщщено вт

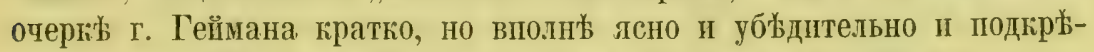
плено краснорбчивыми статистическіми данными и пифрами.

На пространствӝ немногпхъ страницъ составителемъ очерга дано

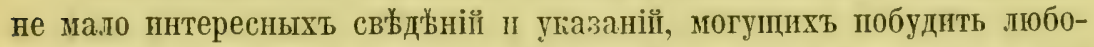
знательнаго читателя къ болье детальному и широкому изученіг тої важной отрасяи сельскохозяйственной промыпленности въ условіяхъ городского и фермерскаго хозяиесва. Въ особенности, поэтому, доджна быть рекомендована бропюра г. Геймана русскому титателю, пю́о нпгд", быть можетъ, какъ въ Россіи, на ея огромныхъ полевыхъ пространствахъ, молочное дъъло не пмъеть столько пголожительныхъ для своего развитія данныхъ и въ смысл娄 важности этой отрасли народнаго хозяйства и въ смыслть той огромной пользы, которую она можетъ принести практическнмъ интересамъ подростающихъ покольній.

31 хекабря 1920 года.

А-ръ К. А. Ковальскій, Ухенъ Американскаго Комитета Союза Сибирскихт Сельскохозяйственныхт Кооперативовъ.

\section{Г. Нью-Іоркъ.}





\section{Молочное Дьло \\ ВЪ СОЕДИНЕННЫХЪ ШТАТАХЪ СЪВЕРНОЙ АМЕРИКИ.}

\section{6 щ я 3 а แ}

Настояпая работа ставить себъ цЊлью сводку имьющихея въ спедіальної литературж данныхъ по вопросу о состояніи молочнаго дъза въ Соединенныхъ Штатахъ Сьв. Америки и характеристику его лишь въ общихъ чертах'ь, поскольку это можеть интересовать русскаго производителя молока съ точки зрьнія улучшенія молочнаго ды да въ Россіп пугемъ занствованія американскаго опыта и новъйшихъ методовъ, прпжыняеныхъ въ этой странъ при разрбшенін основныхъ проблемъ пропзводства и снабженія молокомъ групныхъ населенныхъ центровъ.

,Молого,--пишетъ одинъ пзъ крупнъйшихъ спедіалистовъ по молоку, профессоръ В. Т. Сержвиюъ,-съ древнъйтихъ временъ получнло всеобцее распространеніе І нанлучшую репутацію среди пищевыхь продуктовъ теловъчества."

Сравнительная дешевизна, питательность, легкая переварикость и разнообразная форма употребленія молока создаютъ ему качества уннверсальной пиц, пользуюшейся наибольшиь довъріемъ населенія:

Питательная цжнность 1 бутылки молока равняется: *)

Четыремъ пятымъ фунта свиннны, 15 сент. за фунтъ 12 сент.

$3 / 4$ фунта мяса, отъ 20 сентовъ ва фунтъ.........15 “

8 мйцамъ, 36 сентовт за 1 дюжину.........24 "

3 фунтамъ свъжей рыбы, 12 сентовъ за фунтъ.....36 “

$3 / 4$ фунта ветчины, 20 сентовъ за фунть........

\section{Въ среднемъ 22 сент.}

Между тъ̌м, бутылка выспаго катества. молока въ 1915 тоду стопла 11 сентовъ.

*) Dr. North, Safeguarding Nature's Most Valuable Food-MrLK. 
Значеніе молочнаго хозяйства увеличивается съ калкдымъ годомь не только въ отношеніи размьровъ фннансоваго оборота въ области се.льсго-хозяйственной промышленності, но оно выдвпгаеть болье важную проблему санптарнаго надвора надъ снаб̈женіемъ молокомъ иг уде-

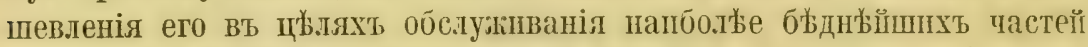
населенія крупныхъ цромышленныхъ цептровъ.

По статистичеспм даннымъ Департамента Земледъ.тія при федеральномь правительствъ Соед. Штатов'ь за 1918 г., молочныиі скотьь (23.284.000 головъ) оцьнивается въ 613.639 .000 долларовъ. Все количество молока, пропзводпмое ежегодно во всеї странж, опредтллется в' 11.590 .000 .000 галоновъ илі 84.611 .350 фунтовъ. Нзъ этого ғоличества поступаеть на пропзводство масла и сыра $46 \%$ г $41 \%$ молока употребляется въ жидкомъ видъ.

Въ видахъ выясненія распредъ.тенія молока среди тородского населенія была предпрпнята весьма пнтересная работа по городу

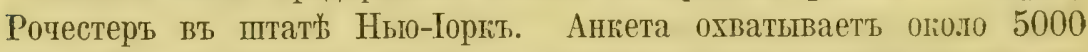
эіттелей, распреджленныхъ въ 15 секціяхт города въ завпспиостп отъ

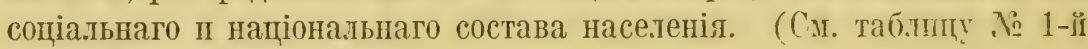
на 14-ї странщщъ.)

Эта таблица съ очевндностыо показываетъ, что численность дыътеї

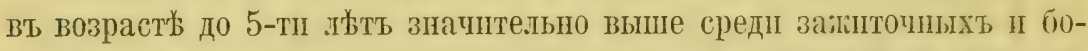
гатыхъ, а количество потребляемаго молока рабочим гізаталами

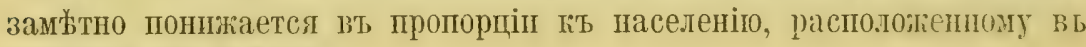
зажниточномь раціонь⿱

Среднее потребленіе молока сравнгтельно не высого--прпб.лзительно одна шестая бутылки на человын ежедневно. Среднії бюджеть американсгої семы обезпешизаеть еї вполит удовлетворите.пное продовольствіе, несмотря на спльное вздорожаніе предметовт пер-

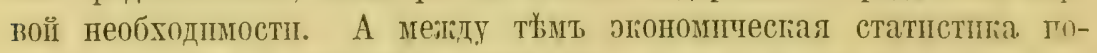

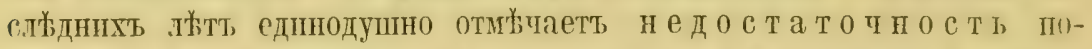
требленія молока отчасті всльддстіе того, тто амерпканское населеніе предпочитаеть пптаться мясної пщщеї.

Профессоръ Колумбійскаго уппверсптета, Г. С. ІІерманъ, предприняль аніету среди 92 семеїствъ среднеї зажиточностп въ Ныо-

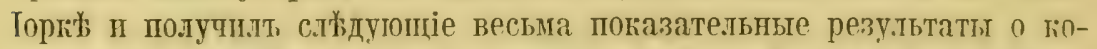
.пгеств' и стопмости пипт. потребляемой одной семьей спедиявно. 


\title{
ПРОДОВО.ІЬСТВIЕ АМЕРИКАНСКОЙ СЕМЬИ.
}

\author{
Средніс растоды Ажерикан. ІІздержин на продоводьствіе \\ семьи ежедневно \\ рекоменд. ироф. Шерманъ.
}

Мясо - рыба .......... 35\%

$12 \%$

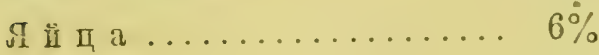

$6 \%$

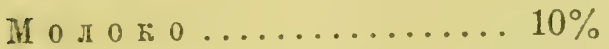

$30 \%$

С и р ъ.............. $1 \%$

Масло и другіе жиры....... $9 \%$

$11 \%$

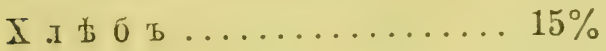

$13 \%$

$\mathrm{C}$ a $\mathrm{x}$ a $\mathrm{p} \approx \ldots \ldots \ldots \ldots \ldots \ldots$

$3 \%$

0вощи и фрукты .......... 13\%

$17 \%$

Профессоръ Шерманъ находить, что пониженіе потребленій мясныхъ придугтовъ сь $35 \%$ до $12 \%$ иі јвелитеніе молочныхъ - сь $10 \%$ - $30 \%$ въ значительної мър' благопріятельствовало бы правильному и болье экономному питаніг населенія.

Нью-Торют является величайшпт пицевымт рынғомь въ Соед.

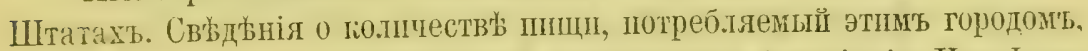
иц находимт въ статпстичесгихъ матерьллахъ Ассосіаціи Ныю-Іоркскихь Һоммерсантовь за 1913 годъ. (См. нижеприведенную таб.лицу).

огазывается, гто пा эти суммарныя данныя краснортипво подтвер-

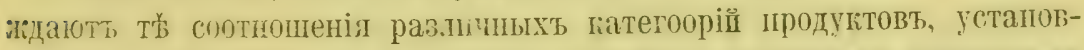
лениия прок. піерманомъ, готорыя служать основныпи предметами пктанія Нью-Іоргской семын. 
ПРОДОВОЛЬСТВЕЕ ГОРОДА НЬЮ-ІОРКА. *)

\begin{tabular}{|c|c|c|c|}
\hline $\begin{array}{l}\text { Назвапіе } \\
\text { ппщевых'ъ } \\
\text { продуктов }\end{array}$ & $\begin{array}{l}\text { Кодичество } \\
\text { Въ фунтах }\end{array}$ & $\begin{array}{c}\text { Стонмость } \\
\text { Въ долларахъ }\end{array}$ & $\begin{array}{l}\text { Проденть общей } \\
\text { имости нищев. } \\
\text { г. Нью-Іорга }\end{array}$ \\
\hline $\begin{array}{c}\text { Мясо и др. мясн. } \\
\text { продукты }\end{array}$ & 800.000 .000 & 413.600 .000 & $34 \%$ \\
\hline Молоко & $\begin{array}{c}800.000 .000 \\
\text { бутылокъ }\end{array}$ & 120.000 .000 & $10 \%$ \\
\hline Масло & $\begin{array}{r}139.000 .000 \\
\text { фунтовъ }\end{array}$ & 111.200 .000 & $9.2 \%$ \\
\hline Сыръ & 28.956 .009 & 14.472 .004 & $1 \%$ \\
\hline Яйца & $\begin{array}{c}151.501 .630 \\
\text { дюжинъ }\end{array}$ & 127.926 .385 & $10 \%$ \\
\hline Хл古65 & $\begin{array}{c}900.000 .000 \\
\text { бу.локъ }\end{array}$ & 90.000 .000 & $7.5 \%$ \\
\hline Caxapъ & $\begin{array}{l}400.000 .000 \\
\text { въ фунтахъ }\end{array}$ & 40.000 .000 & $3.3 \%$ \\
\hline Огородныя овоци & 100.000 .000 & 50.000 .000 & $4.1 \%$ \\
\hline Картофель & 750.000 .000 & 30.000 .000 & $2.5 \%$ \\
\hline Рыба & 150.000 .000 & 30.000 .000 & $2.5 \%$ \\
\hline Кіофе & 45.000 .000 & 13.000 .000 & $1 \%$ \\
\hline Чай & 5.000 .000 & 3.000 .000 & $0.2 \%$ \\
\hline $\begin{array}{c}\text { Крупа и другіе зер- } \\
\text { нов. продукты }\end{array}$ & 5.000 .000 & 5.000 .000 & $0.4 \%$ \\
\hline $\begin{array}{c}\text { Консервы всбхт } \\
\text { продуктовъ }\end{array}$ & & 150.000 .000 & $12.5 \%$ \\
\hline & BCEI & 0.704 .5 & T. \\
\hline
\end{tabular}

*) Eleren Annual Convention of the International Milk Dealers Assosiation, Chicago, December 1918. 
Профессорь химіи Медицинскаго Факультета вт Копельскомь Универсптеть $\mathrm{r}$. Аускъ, доказываеть въ одномъ пзъ свонхт док.ладовъ передт Молочнымь Комитетомь г. Ньо-Іорка, что: „Не должно быть ни одної семьн съ 5-го дътьми, поторал бы погупала мясо для продо-

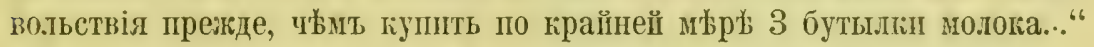
„Мы, продожжаетъ онъ-не можемь ожндать вдороваго общественнаго питанія до тъхъ поръ, пока каждый членъ страны не будетъ употреблять по меньшей мьрб $1 / 2$ бутылки молока ежедневно“.

Молоко представляеть исключительную цинпость, каюъ пища для роста организма и напболъе депевую форму протэнна. Молочная фарма есть питательный центръ Націи.

Въ декабрж мжсящ⿱ 1918 года пропсходпла конференція спеціалистовъ по молочному дылу, гдъ были представлены доглады изъ кругньйшихъ городовъ Соед. Штатовъ (Нью-Іоркъ, Филаде.пффія, Балтиморъ, Бостонъ, Индіанаполисъ и др.) по самымъ разнообразнымъ вопросамъ санитарнаго надзора надъ пропзводствомъ и организаціей снабженія мологомъ городскихъ центровъ. Въ отношеніп потребленія модока въ г. Нью-Іоркб - гонференція принлла сльдующую норму, рекомендуемую проф. Лускъ, проф. Шерманомъ и Д-ромъ Голтъ:

\section{КОЛИЧЕСТВО МОЛОКА, РЕКОМЕНДУЕМОЕ ДЛЯ ПОТРЕБЛЕНІЯ}

ВЪ Г. НЬЮ-ІОРКБ ЕЖЕДНЕВНО.

\begin{tabular}{|c|c|c|c|}
\hline Въ возрасть & $\begin{array}{c}\text { Возрастный составъ } \\
\text { насеелиія }\end{array}$ & $\begin{array}{l}\text { Додя модока на } \\
\text { важдаго }\end{array}$ & $\begin{array}{l}\text { B C E T O } \\
\text { Mолока }\end{array}$ \\
\hline До 1-го года & 130.500 & 1 бутылка & 130.500 бут. \\
\hline Оть 1 до 2 льть & 126.700 & $3 / 4$ бутылки & $95.025 \quad$ \\
\hline Оть 2 до 6 льть & 1.387 .900 & 1/2 бутылки & 693.950 \\
\hline $\begin{array}{l}\text { 0ть } 6 \text { до } 14 \text { льть } \\
\text { Старше } 14 \text { л'ьть }\end{array}$ & 4.092 .342 & 1/4 бутылки & \\
\hline & & 1 стаканъ & 1023.098 \\
\hline
\end{tabular}


Ести взлть эту нориу потреб.ленія молока, основанную на весьма серьезномь пвученіп пг сравнить ее съ количествомъ молока, поставляемым енедневно въ Ныо-Іорғт въ настоящее время, а именно 1.800.000 бутылокъ. то оканется. что около $10 \%$ молога, необходимаго для норма.эьнаго питанія, населеніе г. Ныю-Іорка пе довдаеть ежедневно. Это обстолте.тьство и послужило одной пзъ супественныхъ причинъ возрастаюцаго процента дытской смертности въ быднбйшихъ кварталахъ т. Ныю-Іорка. 


\section{ВЪ ЧЕМЪ ЗАКЛЮЧАЕТСЯ НОВЪЙШАЯ ПРОБЛЕМА МОЛОЧНАГО ДЬЛА ВЪ СОВРЕМЕННОЙ АМЕРИКЬ.}

Съ необычайнымъ ростомъ амернканскихъ городовъ за посльднія 25-30 львть потребность въ свђжкемъ молокь увеличпвается въ громадныхъ разитрахъ.

Вмъсть́ съ тьмъ возникаеть вопросъ во всей его сложности объ у.лучшеніп качества молока п полномъ обезвреживаніп его въ качеств‘ распространителя заразныхъ бользнеиі средіг городского населенія. Старая спстема снаб;енія мологомь становится непрпгодноі. Новыл распредй.лительный механпзмъ молока, складываясь п совершенствуясь весьма медленно, явиля результатомъ напряженной работы органовъ городского самоуправленія іІ другихъ запнтересованныхъ общественныхъ учреляденії, упростивъ тьмъ самымъ задачу санптарно-медицинскаго надзора.

Почти до 80-хъ годовъ прошлаго столь̈тія во всь̆хъ амергканскихъ городахъ молоко поступало на рынокъ не пначе, какъ снятое, подмышанное и разведенное водої.

Лпшь съ 1885 тода дызлагть первые опыты спстематическаго пзсль̈дованія молока путемъ собпранія молочныхъ образцовъ съ отдб.льныхъ фермъ для хпмпко-бактеріологическаго аналпза въ городскихъ .табораторіяхъ.

Въ это время все молоко поставлялось пвъ провпнціп фермерамп непосредственно городскому потребителю препмущественно на лошадяхъ. И хотя потребптель отлично зналь своего поставщпка, однако, пропзводство молога пронсходпло при условіяхъ полнаго отсутствія соблюденія элементарныхъ правиль санптаріп.

Даже въ настоящее время, юогда приняты чрезвычайно разнообразныя и рбшительныя мжры надзора п контроля за пропзводствомъ жолога, опасность распространенія эппдемпческихъ болъзней: туберкулеза, тифиа, скарлатины, дифтерита и различныхъ видовъ поноса черезъ загрязненное молоко, отнюдь не миновала, потому что аме- 
рпканскій обыватель не имђеть обыкновенія кипятить молоко й предпочитаетъ употреблять его въ сыромъ видъ.

- Д-ръ, Розенау нзсльдовалт 551 0бразцовъ сырого молока въ городахъ Чикаго, Нью-Іоркъ, Вашинтонъ, Рочестеръ и т. д. и нашель иъ 46 (или $8.3 \%$ ) образцахъ туберку.тезныя бациллы. Сог.тасно другого авторитетнаго петочника *) - въ 1914 году бы.ло обнаружено 194 туберкулезиыхъ коровы ивт 632 освиджтельствованныхъ. находившихст въ нанболъе образцовыхт молочныхъ фермахъ.

Д-ръ Чар.льсъ Е. Нортъ въ своемъ изсльдованін: „Почему молого доджно быть пастеривовано“ замъчаеть сльдующее-, $25 \%$ всьхь

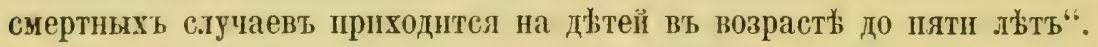

„Больше дытей умираетъ отъ внутреннихъ бользней, чь̆мъ отъ другихъ прнчниь. Дьстская пица состонтъ главнымъ образомъ изъ молока, оно и лвляется важнжйпимъ инфекціоннымъ распространителемъ забольванія и смертности".

Нажъ нбтъ необходнмости умножать приведенные факты, ұтобы подтвердить совершенно очевпдную истину о пагубномь вліянін употребленія не пастеривованнаго молока.

*) Twenty Eighth Annual Report Mass. Agricultural Ex., St. 31. 


\section{САНИТАРНЫЯ УСЛОВІЯ ПРОИЗВОДСТВА МОЛОКА.}

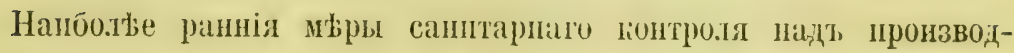
ством', мо:тона оыли предирняты ПІтатными Правительствами противт разбавленія молока водой іп другии суррогатамп, пражтнкуюцееся ІІ до сихъ поръ иъ 10жныхъ и Іентральныхь ІІтатахъ.

Въ настощцее время Зем.ледъ.тьескія Департаменты ШІтатныхъ

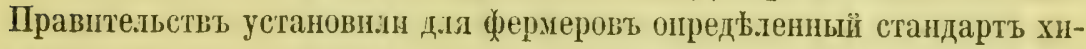
мическаго состава молока, поступаюаго на гороской рыноцъ въ жнгкомъ видъ. Мальйшее отступтеніе отъ этой нормы пресльдуется весьма суровыми наказаніями. *).

На праптик инспекція ограничивается опредыленіемъ тольго жира, п, еслп нолого не зак.лючаеть $3-1 / 2 \%$ жира, то оно не допускается въ продажу в'ь качествж столоваго молока. Інепекція производитея регуляришм объжздов по бермамъ представителями „Штатнаго Бюро здоровья" п, гіром' того, всђ томпаніп, пмьюція молочныя депо въ городахъ, обязаны предстан.ять въ городскія лабораторін ежедненно образцы молока предназначеннаго д.я развоза городскимт потребителямт.

$\mathrm{B} \preccurlyeq$ свою очередь, всъ пастеризаціонные заводы пмьютъ у сео́л нео̆ольшія лабораторіп, въ готорыхъ испытывается молого прежде, чбыъ оно поступаетъ въ буты.очную раз.пвну.

Весь моточный скоть находится подъ спеціа.тнымъ надзоромъ IIтатишхъ ветерннаровт, поторые подвергаютъ осмотру паждуг корову (молочную) въ опредъзены промежутпі времени и снабжають фермеровт соотвћтствуюцими свидътельствами на право доенія коровъ.

За посльднее времл қермера все чаце начпнапт оргапивоваться въ спеціальные пооперативы подъ названіемъ: „Ассосіаціп Нсиытанія Коровъ“, получпвшихт почтп повсемћстное распрострапеніе. Эти ғооперативы постоянно сотрудничаптт, ст. ІІтатными Зем.тедй.льче-

*) MeNutt. The Modern Milk Problem, N. Y., 1917. 


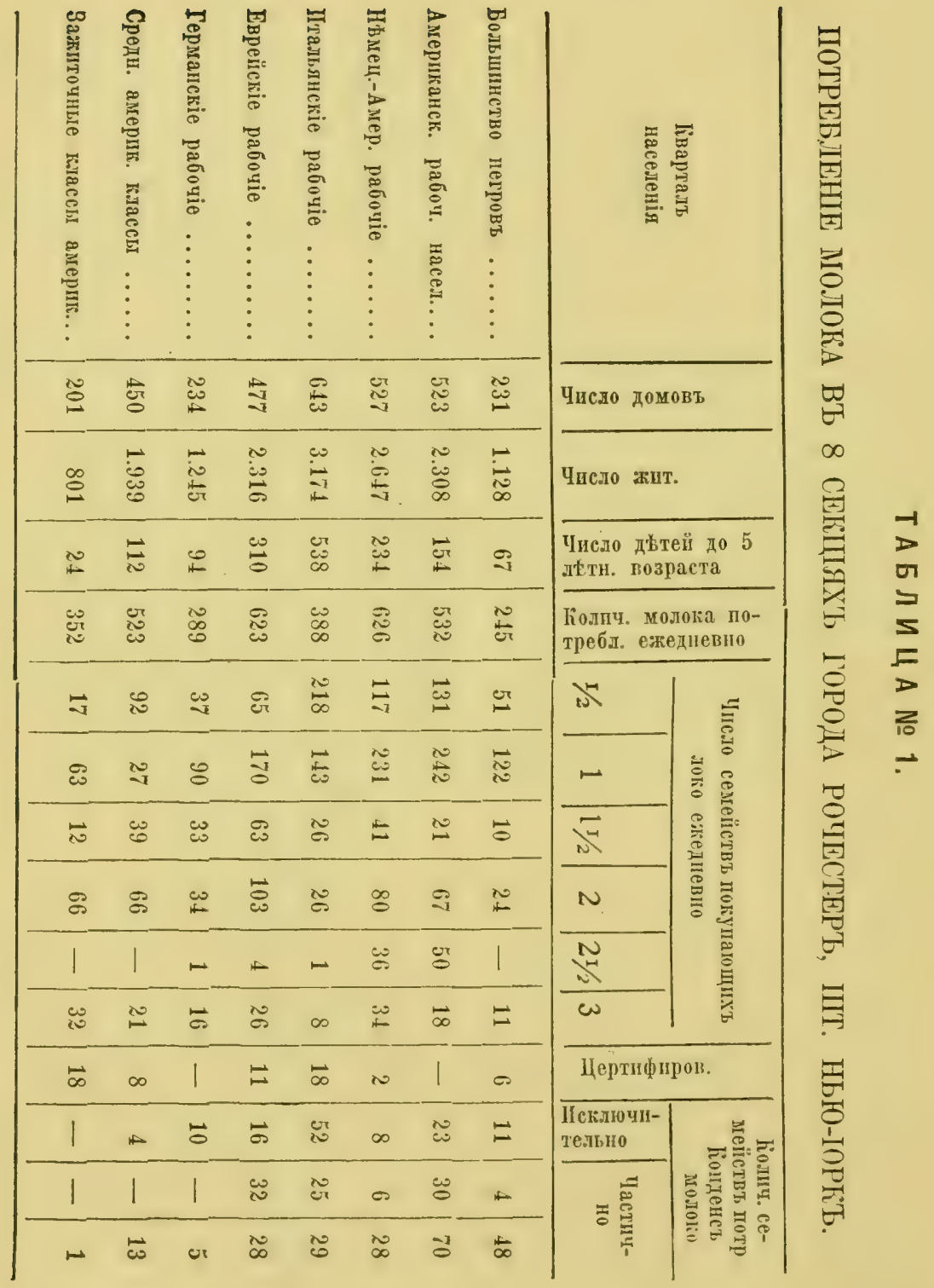


скими Экспернментальными станціями II достигають значптельныхт результатовъ въ дъль, какъ улучшенія породъ молочнаго сгота, тагт

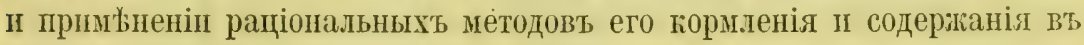
цв.ляхъ увеличенія пропвводства молока.

органшзація санптарнаго надзора въ различныхъ птатахъ имуеть своп особенности и подлежить въдыніг многочисленныхъ учрежіденій: „Штатныхъ Бюро здоровья“, „Санитарныхъ Бюро скотоводства“", „Продовольственныхъ комиссій", „Совътовъ 0бщественнаго здоровья" (при Городскомь Управ.леніп) или Денартамента Земледълія".

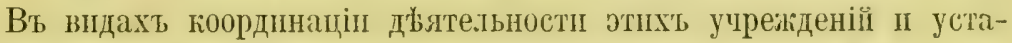
новленія тозлдественныхъ нормъ по пнстругтпрованіг фермеровт, В'э

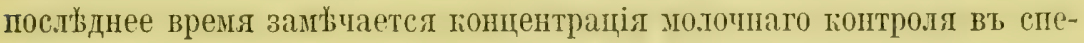

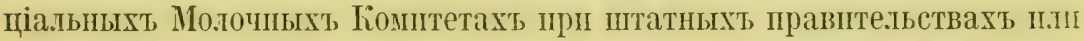
городскихъ самоуправленіяхъ, гуда входять представптели всъхъ запнтересованныхъ іп компетентиыхъ учреждепії.

Эти Комптеты пзучають дъ.то на мъстахъ путемъ разсылки фермерамт разработанныхъ анкеть, оргапизаціеі регулярныхт съъздовъ,

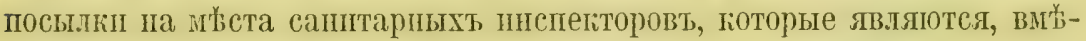

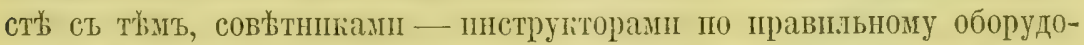
вапію молочныхт, фермт, демонстраторами новыхъ аппаратовъ и проयпхъ усовершенствованій въ молочномъ ховлйств'。

Съ п'ълью распространенія санитарно-гпгіенческихъ внапій, вт,

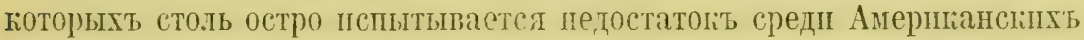
фермеровъ, Молочиые Комитеты ведугъ вспду широкую пропаганду путемь устроїства обравцовыхт фермт па свої счетъ, выставогъ сіота

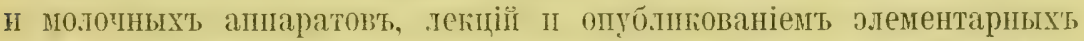

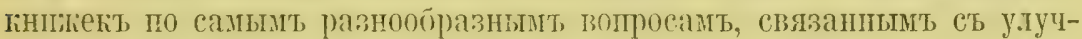

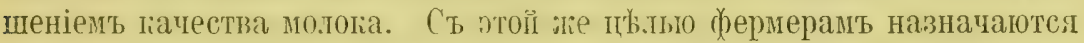
поошритетыны премін ва выспго-тачествениое молого, поставляемое

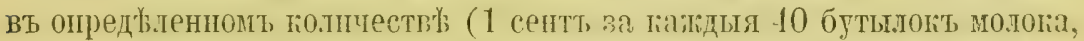
въ тоторомъ огазіетея менше устаповленнаго стандарта бағтерій 25.000 на одинъ куб. сантиметрт).

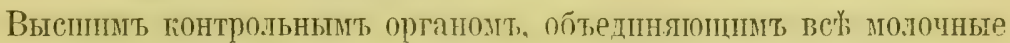

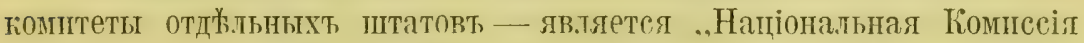
по Стандарализапіп Молоға“.*) Всж санштарно-техническія мүры, реғомендуемыя этої помиссіеї для проведенія въ жшэнь Мояочными Кำмитетами, сводятся къ сль̈дуюпему:

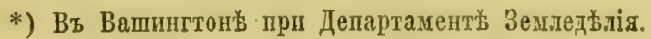


1. 0борудованіе достаточнаго количества .абораторій въ провниціп городахъ для бантеріологическаго изсльдованія молока и степенп его загрязненія во всьхъ фазахъ процесса пропвводства, храненія п транспортпрованія отъ форерхера до городского депо.

Оборудованіе такихъ лабораторії однотипнаго характера обходится отъ 200 до 500 долларовъ.

Въ нихъ можно пронзводить отъ 100 до 200 испытаній различныхъ образцовт молока ежедневно.

2. Наблюденіе за надлежапим содержаніемъ молочнаго скота: цементные полы въ стоїлахъ, хорошая вентиляція, купанье и мытье коровъ, тцательное обмываніе вымені передъ доеніемъ.

3. Наблюденіе за санитарнымъ пропзводствомь молока: стерплизація всей молочной посуды передт доеніемъ, прнићненіе для доенія молока ведерь съ наклонными горламп, предупреждаюпихъ загрязненіе молога; допть не пнате, кагъ сухимп, чистым ругами; весь рабочій персональ до поступтенія на службу должень подвергаться медицинскому освиды̆тельствовапію іп в0 время работы пользуется бблымъ холщевымъ бъ.льем.

4. Молоко должно сохраняться до отправкіп съ фермы п во всьих посльдующихъ стадіяхъ передвикенія въ холодномъ помьщеніи со льдомъ илі помищатьсл въ спеціальные сосуды съ холодной водої такимъ образомъ, ттобы теипература молока всегда держалась въ предъзахъ $40-50^{\circ}$ по Фаренгейту.

5. По возможності, отъ каждої партіи молока, отправляемаго съ фермы въ концентраціонныя станцін, расположенныя на желжзныхъ дорогахъ, брать обравцы іл достав.тять въ б.пжайшую отъ фермера правительственную плю общественгую (городскую п.лі кооператпвную) лабораторію для бактеріологичесгаго изстьвдованія.

Результаты проведенія вышеуказанныхъ мръ санптарно- контрольной админгстрацін могуть быть иллюстрированы слтдующим

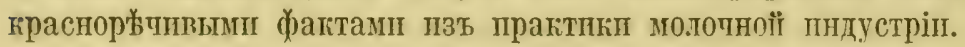

Въ 1917 году багтеріологическія пспытанія молока по всей странъ дали вт среднемь 30.103 бантерій на 1 губ. сантиметрь на гаждый 
образець сырого молока, взлтаго непосредственно съ молочной фермы; іт, 1918 году те же пспытанія дали 10.097 бактерій на 1 ғубб. сантиметръ.

На молочної гонцентраціонной станцін-Спарцъ, въ штатьв Мәрилэндъ, 28 фермеровъ, поставллвшихт ежедневно молоко въ Фн.ладельбію, всльдствіе усовершенствованія санштарно-гшгіеническихъ методовъ доенія п храненія молога, согласно вышеупомянутыхъ инструкцій, понивпли въ теченіе 6-тинедъ.ььної прағтин съ 2.000 .000 до 40.000 бактерій на 1 куб. сант.

Другой опытъ быль пронзведенъ на молочноіі концентрапіонной

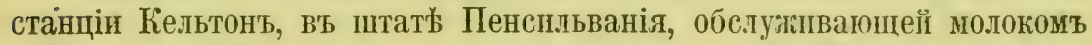
г. Фпладельфію, подъ руководствомъ д-ра С. Е. Норта, директора „Съвернаго Бюро 0бщественнаго Здоровья“, который оппсываетъ этотъ опытъ въ одномъ пзъ свопхъ докладовт сльдуюппмъ образомъ:

„Безъ всякаго предупренденія на станцію Кіельтонъ было послано нъсколько бактеріологовъ, которые въ теченіе 6 дней, съ 29-го марта по 5-ое апръля, брали образпы молока для бактеріологическаго изсльдованія изъ каждаго молочнаго сосуда, вмбъстимостью въ 40 бутылокъ, привозимаго сюда ежедневно съ 54 молочныхъ фермъ, находившихся въ то время в'ь крайне антисанитарныхъ условіяхъ.

„Пятаго апрьлля я вызвалъ 10 фермеровъ, тренированныхъ мною въ районь молочної станціи 0ксфордъ, въ штать Пенснльванія, гдक получались рекордные результаты бағтеріологическихъ пвсльвдованій молока, всльдствіе значительныхъ улучшеній санитарныхъ условій доенія и храненія молока. Съ оксфордскими фермерами я началь демонстрацію на 10 кельтонскихъ фермахъ 5-го апрьљля при соблюденіп сльдующихь условіи:

„1. Доеніе проивводнлось сухпми рукамп въ ведра съ нағлонными горлышкамп, шмьющнми 5 дюймовъ въ діаметрж.

„2. Тпцательное вымываніе п стериливація молочныхъ ведеръ и бндоновт для транспортировки молока.

„3. Захолаживаніе молока путемъ помищенія бидоновъ въ банки съ холодної (40 Фарепгейта) водой или льдомъ.

*) Фарльзъ Нортъ. Доклады, помњщенные въ отчетахъ ,2-го Съъзда дынлтелей по модочному дъзуч“. 1918 г. Нью-Іоркъ. 
4. Во время доенія были пршняты мъры ніь тону, чтобы ВЈ молоко не проникала пыль пзт воздуха. При доеніи прпсутствова.ии пе тольго собственник 10 Кельтонскпхъ фермъ, но и много посторпнихт фермеровъ.

Къ 6-пмъ часамъ вечера доеніе оыло окончено иг угромъ 6-го Апрйля молоко было доставлено на станціо Кельтонъ подъ мопмъ наб-

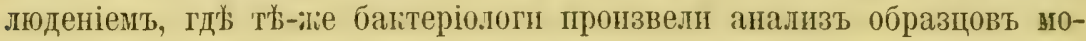
лока съ этихъ фермъ.

„Результаты аналива молога тьхъ жәе коровт за шесть предшествующихъ и один, посльдующій день, представн.лись въ сльдугщем' виды :

\section{БАКТЕРІОЛОГИЧЕСКІЕ ОПЫТЫ НАДЪ МОЛОКОМЪ}

\begin{tabular}{|c|c|c|c|c|c|c|}
\hline \multirow{2}{*}{$\begin{array}{c}\text { Кодичество } \\
\text { бактерії } \\
\text { на } 1 \text { пуб. } \\
\text { сантнмету. } \\
\text { Съ фермы }\end{array}$} & \multirow[b]{2}{*}{28 марта } & \multirow{2}{*}{$\begin{array}{l}\text { ДОЕНІЕ } \\
\text { марта }\end{array}$} & \multicolumn{3}{|c|}{ КЕЛЬТОНСКИМИ ФЕРМЕРАМИ. } & \multirow[b]{2}{*}{5 апрџда } \\
\hline & & & 1 апрьля & 2 апрџля & 3 апрь.тя & \\
\hline$\lambda^{2} 1$ & 1.200 .000 & 1.600 .000 & 60.000 & 60.000 & 57.000 & 1.830 .000 \\
\hline 그 2 & $-\ldots$ & - & 95.000 & 2.800 .000 & 680.000 & 1.520 .000 \\
\hline 象 3 & 570.000 & 910.000 & 810.000 & 380.000 & 1.000 .000 & 4.830 .000 \\
\hline 수 4 & 2.000 .000 & 700.000 & 3.000 .000 & 1.200 .000 & 940.000 & 4.000 .000 \\
\hline$\lambda 25$ & 5.000 .000 & 5.000 .000 & 1.600 .000 & 1.000 .000 & - & 1.450 .000 \\
\hline 강 6 & 290.000 & 1.000 .000 & 600.000 & 3.000 .000 & 2.600 .000 & 3.600 .000 \\
\hline № 7 & 1.400 .000 & $\longrightarrow$ & 320.000 & $\cdots$ & 8.000 .000 & 600.000 \\
\hline x: 8 & 11.000 & 9.000 & - - & 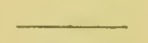 & $\underline{-}$ & \\
\hline 수 9 & 4.000 .000 & 2.100 .000 & 2.200 .000 & 540.000 & 56.000 & 700.000 \\
\hline$\lambda \in 10$ & 1.400 .000 & 800.000 & 380.000 & 1.600 .000 & 1.110 .000 & 500.000 \\
\hline
\end{tabular}

ДОЕНIЕ ОКСФОРДСНИМИ МОЛОЧНИКАМИ

AIPBiII $6-$ - 0 :

显 $1 \ldots \ldots \ldots \ldots . . . . .300$

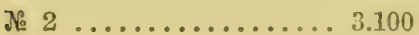

강 $3 \ldots \ldots \ldots \ldots .640$

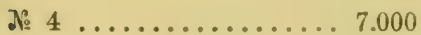

A 5 .............4.100

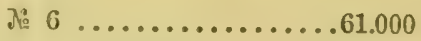

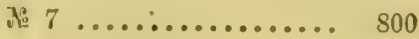

N $9 \ldots \ldots \ldots \ldots \ldots \ldots$

ㄱ․ $10 \ldots \ldots \ldots \ldots \ldots .600$ 
Настоящая таб.лца показываеть поразительный контрасть между колпчествомъ бактерій въ мологъ, полученномъ десятью кельтонскими фермерамп и десятыо оксфордсним отъ тъхъ же самыхъ коровъ.

Вышеописанная доменстрапія лвляется лркої характеристикоі роли ошытнаго фермера въ пропзводствъ чистаго молока; ферма эке са-

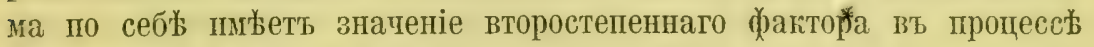
сангтарнзаціи молочної промышленности. ${ }^{*}$ ).

Любопытно отм'ътнть здъсь, что механпческіе аппараты для доенія пе получнли иирокаго распространенія въ Америг, такъ каґъ всь опыты съ механпческимъ доеніемъ не могли устранить три существующцхъ де(екта новопзобрбтенныхъ машпнъ: 1) поврежденіе сосцовъ и высасываніе крови, 2) техническая слонжость оборудованія аппаратовъ, п 3) крайняя затруднительность вымывать посль доенія резгновыя части аппарата.

Размъры настолщеіп работы не позволяютъ подробнъе остановптьсл на главнжйшихъ источникахъ, обслуживающихъ высокое содержаніе бактерій въ молокъ, но энергичная работа американскихъ ветеринаровъ, агропомовъ и молочныхъ санитаровъ дала блестящіе успъхи въ отнопеніи санитарнзадіп молочнаго дъ.ла въ Амерпкъ путем' побужденія фермеровъ, въ ихъ же пнтересахъ, практиковать сльдующіл мъры: 1) обслужнвать ферму свъжеї водой, 2) частое купанье горовъ, 3) цементные полы въ стоіллахъ, 4) доеніе пропзводить въ спеціальномъ помъщеніи и отнюдь не въ стойлахъ, 5) обязатөльное туберкулезное ивслґдованіе молочнаго скота, 6) мытье п стерилпвапія молочной посуды.

Напи наблюденія на эксперпментальныхъ станщіяхъ показываютъ, что проведеніе вышеупомлнутыхъ мьръ по санитарпвадіи производства молога не обременяеть фермера экетренными нздержкками и, въ конечномъ птогъ, можетъ удорожить производство одной бутылки молока, макспмумь, на 1 сентъ, въ то время, какъ на рынкॐ молоко, отвъчающее всњмъ специфоппрованнымъ нормамь санитарнаго контролл, оцьнивается на 6 сентовт дорожне, тумь обычное, негвалифицированное молоко.

*) Cr. по этожу вопросу работу "-ра Норта The Dairyman Versus-“The Dairy." 


\section{ПАСТЕРИЗАЦІЯ МОЛОКА.}

Давно уже прпзнано, что сыро: мо.око представлясть наио̆ольшую опасность въ качествљ распространттеля инфекпіонныхъ болбзHeï.

Въ 1889 г. была пропвведена первая попытка въ Нью-Іоргъ подъ руговодствомъ Д-ра Г. Койлић обезвреживатъ сырое молоко путемъ согръванія его въ буты.лкахъ ири температурй въ $185^{\circ}-195^{\circ}$ по Фаренгейту.

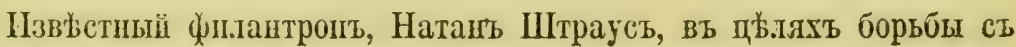
дытской смертностыо, оборудоваль въ 1893 году первое для пастернзащіи дено в’ь Нью-Іорг'ь, откуда бы.о выдано безплатно, за врехя съ Іюня до Ноябрия, 34.000 бутылки пастеризованнаго молока бъднымъ дытямъ. На с.ґдующій годъ бы.10 роздано 306.446 бутылокъ и резу.льтаты оказались сто.ьь б.аготворны на оздоровленіе дызтей, что „Бюро 0бщественнаго Здоровья" и нынгторыя благотворительныя учрежденія начали расширлть дыятельность молочныхъ Депо для безплатнаго кормленія дытей и въ 1906 г. въ теченіе лтта было роздано вт НьюІоргъ 3.140.252 буты.пи настернзованнаго молока. Каґъ это не странно, дътскія молочныя депо и постуніл.ти главной причнной развитія въ Америн, пастеризаціи молока.

.Тучшей п.тлостраціеї вначеніл пастерџвацін могуть служить набпюденія ғрачей, прошведеншя въ дътскомъ госпиталь на Рандаль-

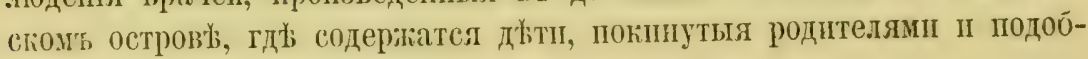
ранныя на улицахт, Нью-Іорка.

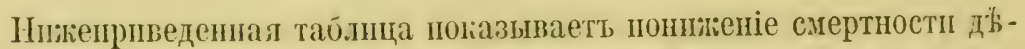
теиі ьт госпиталяхь съ, того времени, когда дытей сталіг кормгть пастеризованныхт молокомъ. 
ДБТСКАЯ СМЕРТНОСТЬ ВЪ ГОСПИТАЛЬ НА РАНДАЛЬСКОМЪ ОСТРОВБ. *)

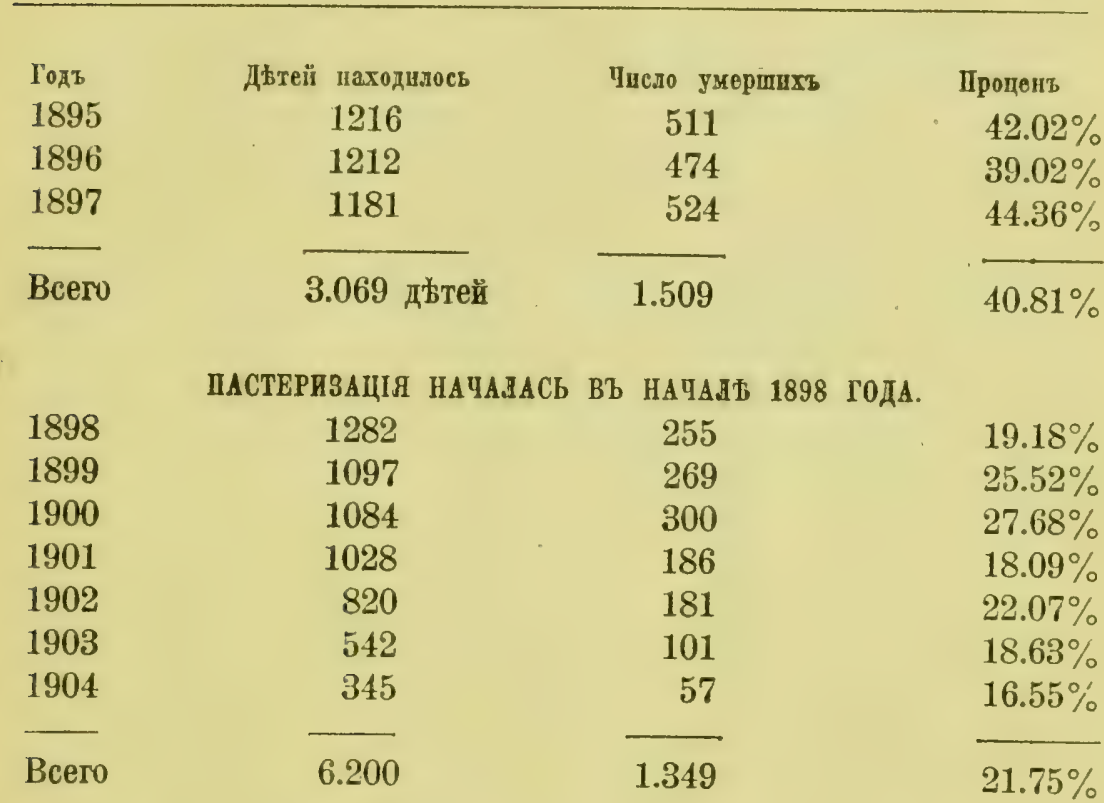

Съ гонца 90-хъ годовъ пастернвація была проведена городскнми II штатными в.тастямп въ законодательномт порлдкъ по всеї странъ, какъ въ провпнцін, такъ и въ городахъ, несмотря на сильное сопрогпвленіе со сторны Распредъ.лительно-Молочныхъ Компаній, таєъ какъ пастерпвація требовала сложныя механическія оборудованія, связанныя съ крупными затратами.

Въ настолцее время ого.т $90 \%$ всего потребляемаго молога въ Ньо-Іоркы - пастеризовано.

Санитарно-техннческимъ контролемъ установлена регуляціонная норма температуры для пастеризаціи молока въ спеціально прнспособленныхъ нагрбвательныхт пубахъ, котлахъ илі системъ двойных' грубогъ для одновременної циркуляціи молока, горячей воды или пара.

*) Parker, "City Milk Supply." 
В'ь каждомъ пастерпзаціонномь депо должны быть приспособлены автоматическіе контрольные аппараты для регістраціи температуры.

Регпстраціонныя ленты ежедневно представляются въ санитарногонтрольныя бюро, п, такпмъ образомъ, достигается полная гарантія, что молоко, поєтупншее на рынокъ, дыйствительно пастеризовани. о чемъ свпдътельствуетъ спеціальная сигнатура на бутылочныхъ пробкахъ и надписп на развозныхъ фургонахъ.

Въ 1913 году нью-іоркская компссія по стандарпвапіп молока опубликовала сльдующую наглядную діаграмму, показывающую неоходимое голичество времени и соотвътствующую температуру для пастерпзапіп молока, при которої убпваются патогенныя бактеріп и пропсходять другіе эфффегты въ пзмьненіп физической п хпмиеской комповиціи молока. Приводимъ эту діаграмму (стр. 23). 


\section{ВРЕМЯ И ТЕМПЕРАТУРА ДЛЯ ПАСТЕРИЗАЦІИ М О ЛО КА.}

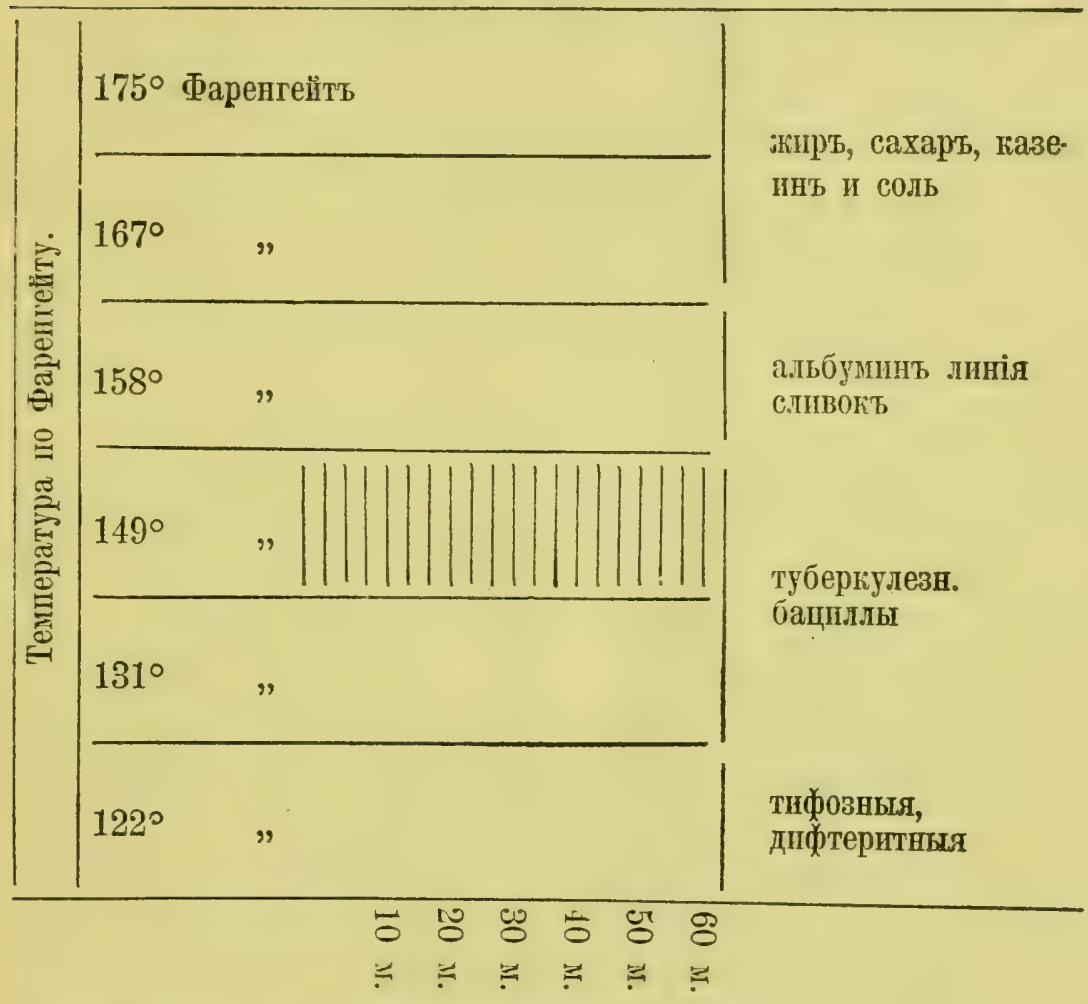

Нейтральнал зона между верхними и ншжими линіями позводяеть свободныц выборъ уровня температуры, прп которой можетъ пастеризоваться молоко.

Да и на прағтикъ мы видимъ, что въ разные періоды времени раз.пиные города варыповали температурнуго скалу для пастеризаціи молока.

Для прнмьра мы приведемъ температурныл нормы, въ двухъ городахъ - Нью-Іоркъ пा Чикаго. 
Нью-Іорнская школа температуры для пастернзацін омлока:

Не меньпе чьыъ - $150^{\circ}$ Фаренгейтъ въ тегеніе не менье 3 мннуть

$\begin{array}{ll}155^{\circ} & " \\ 152^{\circ} & " \\ 148^{\circ} & " \\ 145^{\circ} & " \\ 140^{\circ} & "\end{array}$

\section{В' ЧИКАГО:}

$165^{\circ}$ Фаренгейтъ въ теченіс по менье 1 минуты

$160^{\circ} \quad "$
$155^{\circ}$,
$148^{\circ}$
$140^{\circ} "$

Какъ уже упомлнуто выпе, в'ь настолиее время прағтикется почти всюду температура въ $145^{\circ}$ (Фарепгейть) въ теченіе 30 иннуть.

Въ напу задачу не входитъ описаніе пастерпзаціонныхъ аппаратовъ и машинъ, *) а равно и процессовъ пастеризацін; укажемъ лишь, что въ Америкб прпмъняется 8 раз.личныхъ тппов'ь машинъ, какъ Европейснихъ (Датскіл), такъ и мъстныхъ конструкцін, при этомъ пастерпвація молока въ бутылкахъ въ посльднніе годы соверпенно оставлена нолочными депо, п примъняется главнымъ образомъ, система перегоночная ил трубочная сь прпьненіемъ трбтаго пара.

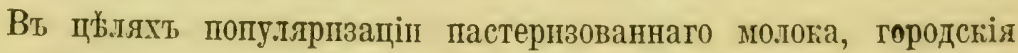
„Бюро Общественнаго Здоровья“" иा коммерческія компаніп широко гользовались рег.ламами, помьцаемыми въ гигіеническнхъ жұрналахъ и газетахъ. Надписн этихъ рекламъ гласили:

„Пастернвованпое молого есть лучшії способъ страхованія жпзни шротивт эпидемпческихт, бользней".

„Матерпнское молого - наплучшее для дотей. Пастеризованне - блюайшее по начеству нт матерннскому".

„Натуральное, чпстое. пастеризованное молоко - лучшая гарантія безопасности".

*) Iиодробнье бб́ этомт, см. напу работу - ..Техника пропзводства сухого и сгущенаго модока" 1919. 
Пастеризація молока, наряду съ бактеріологическими изсльдованіяни и ветерннарной пнспекціей скота, явплась наиолье могуцественнымь средствим' улучшенія пачества молока и оздоров.тенія городского населенія.

Дале въ маленькпхъ мьстечкахъ, гакъ Пало-Алто въ Калифорнін,

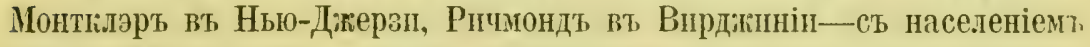
отт 10.000 человъьъ-теперь шмйются оборудованныя пастеризаціоіныя депо, устроснныя ва счетъ городстіхъ самоуправленії или частныхъ молочно-распредъ.лительныхъ тіомпаній.

Америғанскіе санптарные дылтели счптают обслужпваніе на-

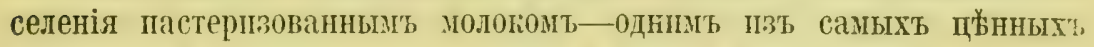
достиженій въ об.тасти санитарнзаціи молочной нндустріи. 


\section{ФИЛЬТРАЦІЯ МОЛОКА.}

Обыкновенное фермерское молоко в’ъ болыпей или меньшеї степенп загрязнено пылыо, во.тсами, гровью пі прочими невидимыми седпментами органшческаго п неорганическаго пропсх0жденія.

Д-ръ Норть счптаеть, что на каждыя 6.000 бутылокъ молока пріходится 1 фунтъ постороннеї натуральному молоку механической примъсн. *)

Санитарныл учрежденія амернианскихъ городовъ предпрпняли цъъ.ый рядъ пзслтдованій для опредъзенія степені загрязненія сырого молока, поступаюцаго на городской рынокъ, І въ ревультать эти изсльдованія прнвелі гъ тому, что вт настолщее время все молого, въ

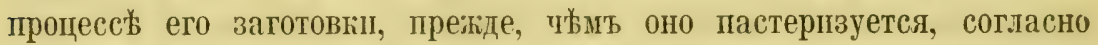
требованія санитарнаго контроля, обязательно должно пропускаться черезъ фильтраціонные аппараты, установленные во всьхъ пастеризаціонныхъ депо.

Насколько велиюо загрязненіе нормальнаго молока, можно судить по сльдующимъ даннымь:

1) Въ 7-ми амернканскихъ городахъ анализы молока дали на 1 літрь отъ 3.8 до 13.5 миллигр. гряви.

2) Въ нысколькихъ норвенскихт городахъ, въ среднемъ, на 1 литръ-2.6 миллпгр. грязи.

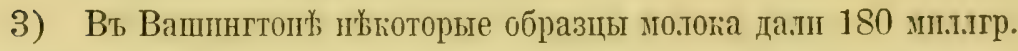

Инспегторт Бюро 0бщественнаго Здоровьл вт Монтк.лэр' (шт. Нью-Джерзи), д-рь Паркеръ, въ своеіі напитальной работь ,The City

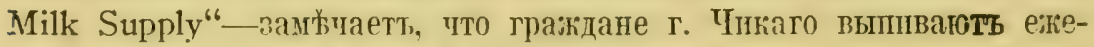
годно въ получаемомъ мологе 25 тоннъ грявн.

По подсчету д-ра Норга в'ъ Нию-Іорк'各 отинльтровывается отъ потребляемаго молока такъ называемой, ,фильтраціонной сливи" ельдневно 333 фунта, что составляеть около 50.000 фунта ежегодно.

*) Report of National Commission on Milk Standard, New York. 
Должно замътить, что результаты біо-химпческих анализовъ амеpцканскихъ лабораторій свидътельствують, что пменно въ нефиньтрованномь молог' содержнуисть бользнетворныхъ бацилль весьма велг ка, какъ это відно пззъ нижегрпводпмої таблицы:

\section{ДВИСТВІЕ ФНЛЬТРАІІИ МОЛОКА НА УНИЧТОЖЕНІЕ Б0ЛБЗНЕТВОРНЫХТ БАЦИЛЛЬ.}

B a r т е p i II

Дифотеритныя

1 обр. щолока 2 обр. 3 обр.

1 обр.

Тпирозныя

2 обр. $\quad 3$ обр.

Количество бактерії на 1 куб. сент. до фильтраціи: $\begin{array}{llllll}400.000 & 1.521 .000 & 2.520 .000 & 245.000 & 460.000 & 756.000\end{array}$

К0.пючество бактерій на 1 куо̆. сент. пос.ть оппщенія молока путемь фильтрацін:

$\begin{array}{llllll}17.000 & 61.000 & 75.000 & 11.900 & 5.000 & 3.000\end{array}$

Процентъ сокращенія бағтерій пос.ть фйльтрацін

95.0 проц. $\quad 96.0$ проц. 97.1 проц. 94.0 проц. 99.7 проп.

Настолщій опыть пріобръатеть особенный пнтересъ, если вспомнить, что въ русской деревнь до сихъ поръ еце крестьяне практикують процбжлгваніе молока черезъ пучолъ лучинъ, вставленный въ горлышко дойнпка съ тьит, ттобы „выловнть червячгіовъ“ пзъ молока.

Въ заключеніе обзора пастернзапіи молока мы приводимъ таблицу, показывающую чпсло городовъ Соединенныхъ ІІтатовъ съ населеніемъ свыпе 10.000 жителей, снабжаемыхъ полностью пли частично пастеризованнымъ молокомъ. 


\begin{tabular}{|c|c|c|c|c|c|}
\hline $\begin{array}{l}\text { Съ населе- } \\
\text { ніемъ }\end{array}$ & $\begin{array}{l}\text { Чнсло гоород. } \\
\text { въ Сосд. ШІт. }\end{array}$ & $\begin{array}{l}\text { Больше } 50 \% \\
\text { потребляется } \\
\text { молока } \\
\text { пастериз. }\end{array}$ & $\begin{array}{l}\text { 0тъ } 11 \% \\
-50 \% \\
\text { потреб. } \\
\text { пастернз. }\end{array}$ & $\begin{array}{c}10 \% \\
\text { потреб. } \\
\text { молока } \\
\text { пастериз. }\end{array}$ & $\begin{array}{l}\text { Совершен } \\
\text { ио не па } \\
\text { стеризуют } \\
\text { молоко. }\end{array}$ \\
\hline Свыпе 500.000 & $\begin{array}{ll}0 & 9\end{array}$ & 7 & 2 & 0 & 0 \\
\hline $\begin{array}{l}\text { Оть } 100.001 \\
\text { до } 500.000 \\
\text { 0ть } 75.001\end{array}$ & 40 & 12 & 20 & 6 & 2 \\
\hline $\begin{array}{l}\text { до } 100.000 \\
\text { Оть } 50.001\end{array}$ & 19 & 5 & 8 & 4 & 2 \\
\hline до 75.000 & 30 & 4 & 15 & 6 & 5 \\
\hline $\begin{array}{l}\text { Оть } 25.001 \\
\text { до } 50.000 \\
\text { Оть } 10.001\end{array}$ & 78 & 13 & 31 & 12 & 22 \\
\hline до 25.000 & 168 & 10 & 40 & 18 & 100 \\
\hline ВСЕГО & 344 & 51 & 116 & 46 & 131 \\
\hline
\end{tabular}

Въ этотъ подсчетъ не вн.лючены города, въ которыхъ прнмбнлется снстема цертификаціп молока, получаемаго оть спеціально пнспектируемаго молочнаго скота, содержнмаго въ пскіючите.льныхъ ус.товіяхъ санитарнато надзора. *)

0бъ этой категоріи молока будетъ рьчь итти въ своемъ ньсть.

Приведенная таблица свидытельствуетъ, что пзъ 314 городовъ вь Соединен. ІІІтатахъ; 213 городовъ уже перешли к'ъ пастериваціи въ 1916 году п, надо полагать, въ текушемъ 1919 году прнижненіе пастерпзацін впачительно увелпчива.тось.

Въ 7-мп крупнðйшихт тородахъ Соедпненныхъ ІІтатовъ, сог.іасно даннымъ Департамента Зем.тедъ.ія въ Вашингтон, процентъ пастернлизованнаго молока представтяется въ стодуюшемъ виды:

\begin{tabular}{|c|c|c|c|c|}
\hline Города & $\%$ & $\begin{array}{l}\text { потребляемаго молока } \\
\text { въ пастериз. виды. }\end{array}$ & $\%$ ne & $\begin{array}{l}\text { ортебляемаго молока } \\
\text { T, пастернз. вндъ. }\end{array}$ \\
\hline Бостонъ & & $80 \%$ & Нью-ТоркЂ & $99 \%$ \\
\hline Yнкаго & & $80 \%$ & Филадельфія & $95 \%$ \\
\hline Детройть & & $57 \%$ & $\begin{array}{l}\text { Ппттсбургъ } \\
\text { Сантъ-Луи }\end{array}$ & $\begin{array}{l}85 \% \\
70 \%\end{array}$ \\
\hline
\end{tabular}

*) Этотт сортт молока обелужнваетъ, гаавнымъ обрразомт, больницы п дътей. 


\section{ЗАХОЛАЖИВАНІЕ МОЛОКА.}

Прп современной системъ снабженія молокомь болыших населенныхъ центров'ь, храненіе столоваго молока продолжается въ теченін продолжительныхъ иеріодовъ времени, необходимаго для его перевозгіг

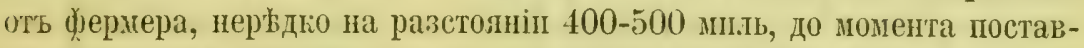
пи тородскому потребителю, па цто требуется въ общей сложности не меньше 40 часовъ. Это обстоятельство вызвало въ амернканской литературь цьлый рядъ спеціальныхъ изсльдованій по вопросу о мето„ахъ захолаживанія молока.

Захоланиваніе молока, кают это погазывають данные приведенныхъ экспернментовъ, не только задержнваеть развптіе вредоносныхь бактерії, но п, наряду съ пастерпзаціеї, способетвуеть уничтоженію iñ b.

Поэтому, санитарно-ғонтрольныя учредіденія почти новсенғстно требуюсъ отъ пронзводителей н распредъпте.тей молога, чтоо́ пос-

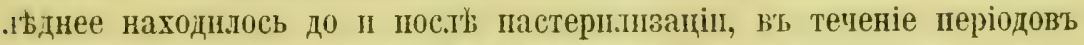
храненіл его, въ температурғ минимумь $15^{\circ}$ по Фаренгейту.

Въ пастернеаціонныхъ депо для захолажнванія молока обычно

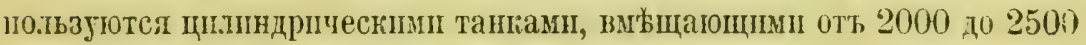
бутызокт молока, съ реф̆ритираторными стьнгамп.

Въ этн бакі молоко поступаеть по трубкамъ изъ пастернзаціонныхъ нагрывате.іеї и въ теченіе по:тучаса успьваеть охпадиться до $45^{\circ}$ фаренгейта.

Д.яя предотвраценія отстанванія сливокъ, вт танкахъ прндылы-

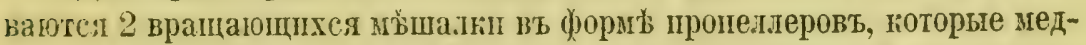

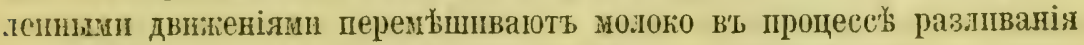

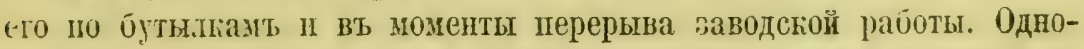
временио эти танкі слунать мъстомь храненія молока, особенно вт тьхь с.ууцаяхт, юогда остается избытого сь одного дня до сліддующаго.

Во время транспортировкг молока, безотноспте:льно разлито .ли

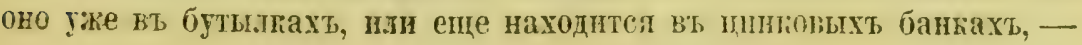


молочная посуда объладывается рубленнымъ льдомъ тагъ, чтобы температура молока не поднималась выше $45^{\circ}$ Фаренгейта.

0 томъ, въ какой степени вліяетъ захолаживаніе молока на процессь бактеріализацін, нижеприводимые результаты опытовъ, полученные на образцовыхъ ферамхъ Әйери и Жансонъ, могутъ служить sркой характердстикой. *)

*) Parker-"City Milk Supply." 
ЭФФЕКТЫ РАЗЛИЧНЫХЪ МЕТОДОВЪ ЗАХОЛАЖИВАНІЯ ПАСТЕРИЗОВАННАГО МОЛОКА НА РАЗВИТІЕ БАКТЕРІЙ.

Способъ захолаживанія

추 1. Сырое молоко

Захоложено быстро.

№ 1. Сразу посль пастерізаціп

Выдержано въ темп. $45^{\circ}$ $\Phi$. въ теченіе 32 час.

Выдержано въ темп. $75^{\circ}$ $\Phi$. въ теченіе 6 час.

Выдержано въ темп. $75^{\circ}$ Ф. въ теченіе 24 час.
Образцы молока въ бутылкахъ

Количество ојактерій на 1 куб. сентим.

1 способъ 2 способъ 3 способъ

9.050 .000

11.900 .000 $\begin{array}{lll}6.450 & 2.100 & 9.500\end{array}$

$\begin{array}{lll}5.050 & 1.720 & 28.000\end{array}$

$\begin{array}{lll}4.800 & 2.340 & 76.000\end{array}$

$1.370 .000 \quad 885.000$

№ 2. Захолаживаніе медленное.

Сразу посль пастеризаціи

7.150

2.580

11.900

Выдерж. въ темп. $75^{\circ} \Phi$.

въ теченіе 5 час.

6.100

1.600

29.000

Выдерж. въ темп. $45^{\circ} \Phi$. вь теченіе 17 час.

6.200

2.400

142.000

Выдерж. въ темп. $75^{\circ} \Phi$. въ теченіе 6 час.

9.600

2.740

348.000

Выдерж. въ темп. $75^{\circ} \Phi$. въ теченіе 24 час.

$2.760 .000 \quad 850.000$

№ 3. Охолояндено въ помьщеніи съ темп. воздуха 75 Ф.

Сразу пость' пастерпвацін

При выдерж. въ теч. 5 ч.

При выдерж. въ теч. 22 ч.

При выдерж. вт теч. 28 ч.

При выдерж. вт теч. 66 ч. 460.800 .000
$4.950 \quad 2.180$

$6.850 \quad 2.890$

700.000

2.420 .000

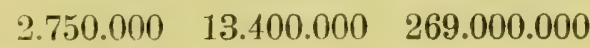

$\begin{array}{lll}2.750 .000 & 13.400 .000 \quad 269.000 .000\end{array}$

8.500

25.000

834.000 
Нзъ этой таблпцы вндно, тто пис:10 бацилт не увелпчивается (примьры 1 и 2), когда пастеризованное модоці, разлитое въ горячемь видж, ох.таждается въ теченіе 5-ти часовъ, несмотря на то, что температура юь предълахъ отъ $80^{\circ}$ до $100^{\circ}$ Фаренгейта наиболье благопріятствуеть бактеріальному развитію.

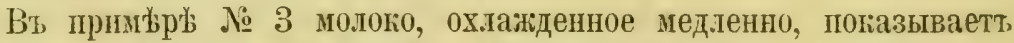
увеличеніе количества бактерій въ сравненіи ст тьм, воторое былю захоложено быстро; но тьзь не менье сльдуетт, замбтить, что данный опытъ пронвведенъ быль въ исключительныхъ условіяхъ медленнаго охлажденіл. Тагимт образомъ, можно ваключить ивъ трехт приведенныхт, примжровъ, тто процессъ охлажденія не долженъ продояжаться болье 5-ти часовъ и сльдовать непосредственно посль онончанія пастеризаціи въ температурь по возможности низкой.

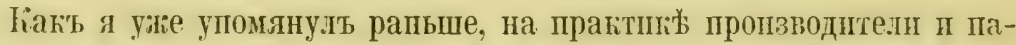
стеризаторы молока примбнлють температуру для захолаживанія и храненія-въ $45^{\circ}$ Фаренйгейта и самый процессь захолажшванія продолюается обычно не больше 30 минутъ, въ теченіе которыхъ молокі пробъгаеть по холодильнымъ трубғамъ, откуда оно поступаетт, въ пцлиндрнческіе резервуары-холодильники для дальнъйшей разливкн п' бутыльамъ.

Ойыкновенно фермера тольюо что подоенное молого собираютт.

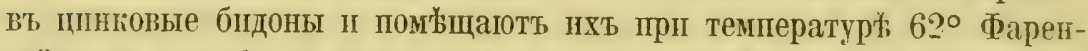
гейта вт погребъ на цементный поль, пли ставять в' проточную йли стопую воду съ температурой $52^{\circ}$ Фаренгейта. 


\section{КЛАССИФИКАЦІЯ МОЛОКА.}

Съ установленіемъ санитарнаго контроля надъ молокомъ, есте ственно, явилась другая, столь же важная, задача - њасснфикаціл ими градація молока.

Массовой потребитель обычно подраздъ̆ляеть молоко на, „плохое и xopomee ${ }^{66}$.

Въ то время, какъ почти всб пищевые продукты на рынкьлийа, жасло, мясо, зерно і прочее сортируется по свонмъ качественнымъ свойстванъ и цынъ, - молоко остается недефедированнымъ, несмотря на т0, что качество и дьна его могутъ значительно варьироваться въ вависпмости оть харағтера пронвводства и потребнтельскато назначенія.

Классифинація молока лотически основывается на санитарныхь крнтеріяхъ, опредж.ляющихъ назначеніе молока, простьйтее подраздыленіе котораго можетъ быть представлено въ сльдующемъ виды:

1. Молого для дътей и больныхъ.

2. Молого для взрослыхъ.

3. Молоко для варкіг и фабрнчнаго употребленія.

Соотв бтственно съ этой класспфикаціей, въ Нъю-Торкъ установлена сльдующая система грададіп молока, опубликованная Департаментонт Здоровья вт сборнићь ,Запонов'ь пा Постановленій пасательно молока и сливокъ".

\section{КЛ А С С Ъ А.}

\section{Сырое молоно.}

Молочныя коровы должны находиться въ хоропемъ физическомъ состолніи и ежегодно подвергаются туберкулезному освндђтельствованію. 


\section{Пастеризованное молоко.}

Не требуется туберпулезное оспидтгельстованіе горовъ, но молочный скотъ долженъ быть здоровымь іл ежегодно инспектированъ ветерннарными властями.

Бактеріологическій предъль-200.000 бактерій на 1 куб. сент. до пастеризацін.

\section{КЛ A C C b B.}

\section{Пастеризованное молоно.}

Молочный скоть долженъ быть здоровымъ п ннспектированъ ежегодно.

Туберкулезное освидътельствованіе не требуется.

Бактеріальный предњль до пастеризапіг 1.500 .000 , если молого пастеризовано въ городъ, и 300.000 , если пастернзація-внб города.

Посль пастеризацін-50.000.

\section{К Л А С C B C. \\ (Для варки и фабричнаго пронзводства.)}

\section{Пастеризованное молоко.}

Въ отношеніп скота аналогичныл требованія съ классомъ В.

Бактеріалыый предж.ть до пастеризаціи 1.000 .000 , посль паетеризацін-50.000.

\section{Пастеризованные сливки.}

Тъ-же нормы по отнопенію молочнаго скота, но мыняется предыль бактеріальности.

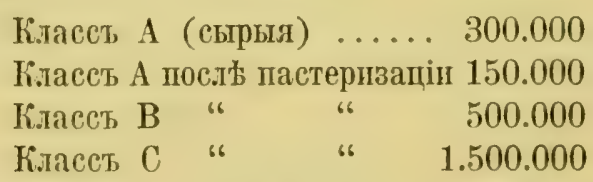

Согласно инструкцін 16-го февраля 1917 года, разработанноя қомиссіей по стандраднзаціи молока (назначенної Молочнымт, Lомптетомъ города Ньг-Іорга), пропзводство градуцрованнато молога должно проходить подъ постоянньмь коптролеиъ санитарныхъ учрежіденій, и перерывы во времен инспекпій всжх фазъ пропвводства молога не могуть длиться больше одного мъслпа. 
Всъ пастеризаціонныя депо, отпускающія свыше тысячи бутылокь ежедневно, - обязаны доставлять въ Департаменть Здоровья регистраціонныя ленты съ автоматическихъ аппаратовъ, показывающія температуру, при которої пастеривовалось молоко.

Всь установленныя нормы грададіи молока представляють лишь минимумъ требованій въ отношеніи Нью-Іоргіскаго штата.

Съ введеніемъ спстемы пастеризацін, цъны на молоко не могли сохраниться въ прежнемъ видъ, такъ какъ оборудованіе пастеризаціонныхъ дего требовало большихъ затратъ, особенно въ тьхъ случаяхъ, когда молочно-распредълительныя компаніи производять сбыть молока. въ массовыхъ размжрахъ, выпуская ежедневно съ одного депо отъ 25 до 75 тысячь бутылокъ молока.

Въ Нью-Іоркб́⿱㇒⿻二乚㇒ бутылка пастеризованнаго молока выспаго качества „A“ - продается на одинъ центъ дороже, чбиъ молоко градаціи „, $\mathrm{F}^{“,}$, а „C“, предназначенное для варки и другихъ промынленныхъ цьзей, продается на 2 сента дешевле „ББ“

Практика показала, что потребитель охотно переплачиваеть лишній сенть за градуированное молоко, получая гарантію, что онъ покупаеть квалифицированное молоко, прошедшее черезъ авторитетный контроль.

Напбольшию распространеніемъ въ американскихъ городахъ пользуется молоко традаціи „Б“, препмщественно среди населенія съ средним'ь достаткомъ; бъднота предпочитаеть покупать молоко градаціи „C“ ІІ, наконецъ молоко „А“, обслужнваеть спеціальную категорію потребителей: дътей и больныхъ.

Что касается такъ называемаго ,цертифированнаго“ молока, то оно почти не входитъ въ кругъ коммерческаго оборота, такъ какъ производится только на спеціально оборудованныхъ фермахъ, гды молочный скотъ находится подъ исключительно строгимъ контроленъ. Это иолоко поступаетъ на рынокъ въ весьма ограниченныхъ размърахъ.

Всъ восточные птаты уже перешли къ спстемъ градуированія молока; южные Іг западные штаты въ этомъ отношенін отстагтт, хотя съ каждымъ годомт, по мърб усвоенія муниципальныи управленіями пастеризаціи молока, зам'ьчается тенденція его квалифицированіи по 3-хъ ғассной системь. 
Комиссія по стандаризаціи молока резюмируетъ свой взг.лядъ на класспфнкацію сдадующни образомъ:

„Продажа клсаснфицированнаго молока на основь качественныхт прнзнаковъ, когорые включають не тольюо химическую композицію, но н характеристику санитарныхъ условіі производства, ды.лаютъ в0зможнымъ для потребителя сознательный выборъ молока по одной только бутылочнов сигнатуръ“. 


\section{ОРГАНИЗАЦІЯ ПЕРЕВОЗКИ МОЛОКА ОТЬ ФЕРИЕРА въ горОдъ.}

Соврененная система транспортировки модока въ крупные ахернканскіе города достигла изумительнаго совершенства.

Амернканцы, б.лагодарл своему техническому генію и удивительной практической сноровћ' І изобрбтательности, преграсно сгравнлись съ одной изъ сложньӥшнхъ задачъ въ молочномъ дылы. *)

Ми постараемся лишь схематпчески опнсать , канализацію" цолока оть фермы до города.

Всюду в' провницін модоко скупается молочными компаніями у фермеровъ и кь 5-6 часанъ вечера свозится въ жестяныхъ бндонахъ на ғонцентрапіонные пуниты, устроенные на жельзно-дорожныхъ станпіяхъ. Ночьо оно погружается въ спеціальн оборудованные рефрижераторные вагоны, прпип.темые къ экспресснымь пођздамъ и къ раннему утру оно успьваеть пробъгать разстояніе вь 400-500 миль. чтобы поспьть въ соотв'ьтствюшій своему назначенію городъ. Съ вон:зала оно развозится вт, громадныхт тельгахъ, прицћпляемыхъ къ снльнымъ автомобплямь-грузовнкамъ, по пастернзащіоннымъ депо, расноложеннымъ въ различныхъ частяхъ города.

Съ 9 часовъ утра до 6 часовъ вечера производится подготовюа молока для распредйлнія среди тородскпхъ потребнтелей. Она сводитея кь сльдугшему:

Изъ бидоновт молоко, посль' внотпней инспекпіи пвъта и запаха спеціальнымт служапцмћ, сливается в' больпую пріемочную цистерну, отюуда оно помпам выкачпвается п пропускается черезъ фнльтрапіпнпую пентрофуту (,кларпфикэйшонь“, по амернканско терминогологін). Затьи молоко собнраетсл въ рефрижераторные резервуары (съ температурой въ $45^{\circ}$ Фаренгейта), гды остается на короткое время, потомъ оно подвергается пастернвапіонному процессу.

\#) Сх. приложеніс „Снабженіе золокомъ т. Нью-Іорка“. 
Посль пастерпзадіп молого автоматически поступаеть по трубамъ въ разливочный (по бутылкамъ) отдъљљ. Одновременно, по системь непрерывности, идеть ниспекція иі стернлизація стеглянной посуды, автоматическая укупорка бутылокъ, укладга пхъ въ деревянные люцин, продвигающіеся по понвеерамъ въ холоднльныя помьценія, гдъ засыпаются мелкнм льдомь, и въ такомь відж остаются вт холодномъ помжшеніи до 2--3-хъ часовъ утра, частью же эти ящики погружаютея сразу на большія тельги, на которыхъ молого развозится въ районныя отдй.ленія депо, обслуживаюпія разлпныя, небодыпія по размьрамъ секціи торода. *)

Съ трехъ часовъ ночи молочные лщики (въ 16--20 бутылокъ) перегружаются изъ холодильнаго помжщенія на 4-колесные фургоны, запряженные лошадьми, и начинается развозка молока по ивартирам ь городскихъ потребителей.

Если пастеризаціонное депо находится въ провинціп, то обычно тамъ же пронзводится разливка молока по бутылгамъ, въ которыхъ оно поступаеть въ городъ для дальньйшаго распредъленія.

Въ среднемъ проходитъ 36 часовъ со времени доенія горовъ прежде, чъ̌м молоко поступаетъ непосредственно къ потребптелю.

Быстрота жельзнодорожныхъ сообщеній, изобнліе линій и на.инность спедіально оборудовағныхъ вагоновъ съ рехри:кераторами- - позволяетъ городскимъ потребптелямъ питаться свъ̌жимъ молокомт. получаемымъ изъ весьма отдаленныхъ районовъ, въ любое время года въ неограниченныхъ количествахъ.

*) Вт льтнее время тельги закрывапося глухпмъ кузовомт, а молочные ящики тщательно засылаютсл мелкимъ льдокт. . Въ этомъ случаћ телґга можетъ оставатьея 5-6 часовъ подъ горячим соднцемт при температурб кодока вт 50-60 Фаренгейта, 


\section{РАЗВОЗКА МОЛОКА ВЪ ГОРОДАХЪ.}

В' городскої транспортпровъ молога за постығніе годы пропзо-

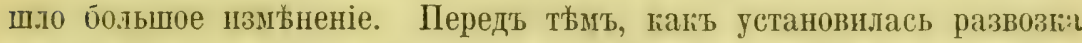
молога въ стенляныхъ бутылюахъ, молоко поставлялось въ ліестлныхт банкахъ, пзъ которыхъ разливалось спеціальными мбрами на улицћ у дверей потребителя, причемъ, первые покушатели получали молоки лучшаго качества, ч'ьм посльдующіе.

Въ 1906 году г. Вай ивсльвдоваль 40 образцовъ молока въ гор. Кливлендъ, взятыхъ у семи различныхъ развозчиковъ и нашелъ, что „глубокое мотого (со дна) въ бангахъ, продаваемое--,разливнымт способшмъ“ на улицахъ, заключаетъ въ себъ на 300\% бактерій больше, чжыъ то же молоко, ио развозиое въ бутылкахъ. Теперь әтоть спосойъ совершенно запрецень затономт и разовзка молока произво- дпитя только въ стеризованных' (паромь высогано давленія) стек.яныхт, бутылкахт, загуноренныхъ автоматическими машинамп. Всћ; развозчики молока предварительно проходять краткій курсъ обучені: и внакомятся съ методами привлеченія потребнтелей, санитарными способами развозғи молока и вообще значеніемь санитаріи въ молочномъ давы。.

Развозчики выполняютъ роль комиссіонеровъ, отъ нихъ зависить успьхъ продуктивности компанін. Поэтому, нхъ трудъ оплачиваетея выше неквалифццированнаго рабочаго-обычно 38 долларовъ въ недъъю, помпмо $2 \%$ съ вырученной суммы.

Молого развозится въ фургонахъ, тщательно окрапенныхъ вт пркій цвйтъ, препмущественно бълый. Для предотвращенія шума, вызываемаго ночнымъ двнкеніемъ фургоновт, въ нбкоторыхъ городахъ (Броктонъ) голеса фургонов' обтягиваются резиновыми шинапм.

Одновременно на этіхъ фургонахъ развозятся яйца и молочные продукты: сыр', мас.ло ІІ прочія пищевые продугты, получаемые ні ()ермахъ, принад.тежащихъ молочнымт трэстамь „Борденсь Ко.", „Шефффильдъ“" п др.

Расходы на развозку молога находятся въ зависнмости отъ коли- 
чества бутылокъ нли полу-бутылокь, погружаемыхь на одном' фурroHt.

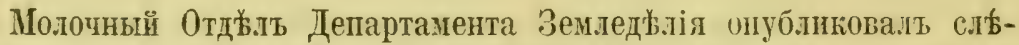
дующія данныя о средней погрузкь фургоновъ въ пяти городахт (Паркеръ - указанная работа).

\begin{tabular}{|c|c|c|c|c|}
\hline Названіе города & $\begin{array}{c}\text { Чиело } \\
\text { фургоновъ }\end{array}$ & $\begin{array}{c}\text { Средній } \\
\text { пробьгъ } \\
\text { фургона } \\
\text { въ день }\end{array}$ & $\begin{array}{l}\text { Средняя } \\
\text { погрузіа } \\
\text { фург. въ } \\
\text { квартахъ }\end{array}$ & $\begin{array}{c}\text { Средняя } \\
\text { погрузка } \\
\text { модока въ } \\
\text { гаяонахъ }\end{array}$ \\
\hline Питсбургъ & 125 & $14.20 \mathrm{Mr}$. & 327.0 & 73.5 \\
\hline Балтимора & 182 & 20.20 м. & 215.0 & 69.3 \\
\hline Бостонъ & 305 & $20.35 \mathrm{M.}$ & 245.0 & 74.0 \\
\hline Дистрнкть Колумбія & 173 & $18.60 \mathrm{M.}$ & 301.8 & 76.3 \\
\hline Фнладельфия & 571 & & & \\
\hline
\end{tabular}

Нанболыпее зло вт современной систем' городской транснортировкі молока заключаетея въ ненужныхъ объъздахъ тьхъ же самыхь каврталовъ фургонами различныхъ компаніі.

Нерђдко юъ одному и тому же дому подъжзжаетъ по утражъ $5-6$ фургоновъ конкурирующихъ компаній. Это ненорма.тьне явленіе вызываеть нагладные расходы, удоражнвающіе стопмость молока за счетт, потребительскаго кармана. Опыты мунцципальнаго и кооперативнаго снабженія нолокомъ при одномъ центрапьномъ пастернзаціонном деню ноказываютъ, что развозка молока безъ повторныхъ объжздовъ тождественныхъ кварталовъ даеть экономію на $1-1 \frac{1}{2}$ сента съ бутыли молока. 


\section{ВЫБоРъ МОЛОчнОГО СКОТА.}

Какъ пзвъстно, домашніиі скотъ появилсл на амернанскомъ понтиненть впервые посль второго путешествія Колумба въ Амершку в'ь 1493 году. Съ этого времени онъ привозился изъ Европы (Испанін, Нталіп иі других странъ) п развозплся по всему побережью Центральной их Съверной Америки ип въ теченіе 3-хъ стольтій гультивировался спеціа:ьный типъ молочнаго скота, оцыниваемаго съ точки зрынія ко.ичества пи ћачества (проценть содерінимости молочнаго жира) пронзводимаго молока.

Самое осторожное изсльвованіе Американскихъ спеціалистовъ по скотоводетву не дали положительныхъ выводовъ 0 томъ, какая порода коровъ нанболье прнбыльна д.ля молочнаго хозяйства.

Среди Американских фермеровъ наблюдается грайнее разнообразіе нндивидуальныхъ вкусовъ въ выборж молочнаго скота.

Наноольшее распространеніе въ Соеднненныъ Штатахъ получнли сльдующіе породы молочнаго скота: *)

\section{ПоРОДЫ моЛОчнЫХъ КОРОВъ И ИХъ ПРОИзВоДИ- ТЕЛЬНОСТЬ:}

\begin{tabular}{|c|c|c|c|}
\hline Названіе породъ & $\begin{array}{l}\text { Продјктивность } \\
\text { молока за годъ }\end{array}$ & $\begin{array}{c}\text { Продуктивн. } \\
\text { модочн. жира вт } \\
\text { фунтахъ }\end{array}$ & $\begin{array}{c}\text { Процентт въ } \\
\text { среднемъ модоч } \\
\text { наго жира }\end{array}$ \\
\hline $\begin{array}{l}\text { "Гольдштейнъ - } \\
\text { Фризіанъ“ }\end{array}$ & англ. ф. & англ. фо. & \\
\hline Нспытаніе пронзве- & & & \\
\hline дено надъ коровами & оть 20.405 & oTt $\quad 953$ & 01'ъ $3.12 \%$ \\
\hline вь 10 фермахъ. & доо 30.452 & до 1.176 & до 4.56 \\
\hline ,,Эйшаръ“ & & & \\
\hline Опить произведень & отъ 17.567 & $\$ 21$ & отъ $3.35 \%$ \\
\hline въ 11 фермахъ. & до 25.328 & 895 & до $4.6 \mathrm{\sigma} \%$ \\
\hline
\end{tabular}

*) „Паркеръ“. Јказанпое сочиненіе. Матеріалы Департамента Земледъдія, Ващингтонъ. 
Продуктивность

Названіе пород'ъ

Браунъ Свиссъ“

„Гуэрнси"

Опыть пронззедент

на 10 фоермахъ.

"Джерзи"

(Смъшан. порода

Франц. - Британск.

происхонден.) опыть

10 фернъ.

\section{,Французско-}

Канадская"

въ среднемъ

\section{,Американъ Шортъ Хорнъ'*}

Опыть пронзведнъ

на 10 фермахъ. модока за годт

отъ 9.448.8

0ть 14.686

до 24.008 молочн. жира въ фунтахт

363.7

0r\$ $\quad 899$

до 1.098

OTJ $4.54 \%$

до 6.12 наго жира

$3.84 \%$
Іродувтві.

Ilpoteliт въ среднемт молоч-

\begin{tabular}{|c|c|c|c|}
\hline отъ $\quad 6.896$ & OTъ & 560 & OTъ $5.12 \%$ \\
\hline до 18.782 & до & 962 & до 8.13 \\
\hline
\end{tabular}

Пос.эвнюо категорію молочнаго спота составляеть скоть , твойного назначенія", қомбннирующій типческія особенности молопнхь

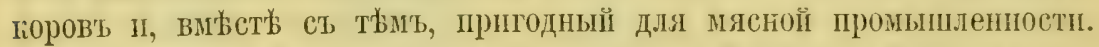

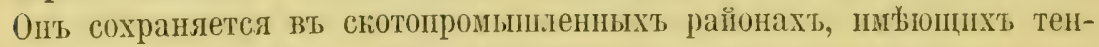
денцію перехода къ молочному хозяисств.

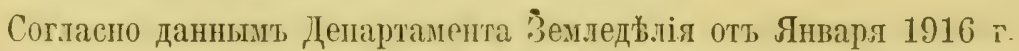
въ Соединенных ШІтатахт, на ферлахт наспитывалось-22,768.000

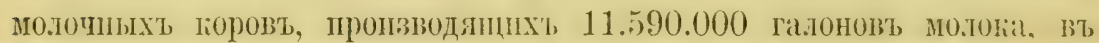

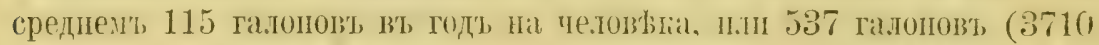

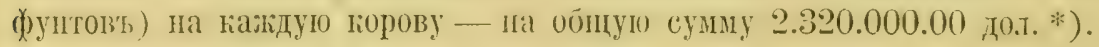

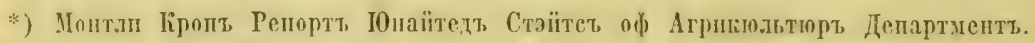
2) 11916 г. и Д-р- Нортъ вт своеї работж „Методъ Молочн. производста“ опре-

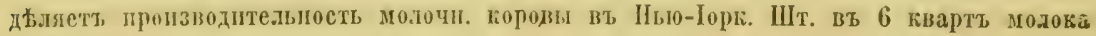
ежедневіо. 
Стонмость молочнаго скота оцьниваетея въ 1.185.114.00 доп:аровъ, а одной коровы ириблизительно 54 доллара.

Чтобы представіть себ'ь количественный ростъ и стонмости молочнаго скота въ пропорцін къ росту населенія въ Соединениыхъ Штатахъ за періодь времени сьь 1880 по 1916 г.1., мы прпивдим нанболье достовърныя данныя, опуолиюованныя Департаментомь Земледълія въ статистическомь ежегодникь Соедин. Штатовъ за 1915 годъ:

\section{РОСТЪ МОЛОЧНАГО СКОТА ВЪ СОЕД. ШТАТАХЪ.}

\begin{tabular}{|c|c|c|c|c|}
\hline Годы & $\begin{array}{l}\text { पисденность насе- } \\
\text { хенія вт Соед. Шт. }\end{array}$ & $\begin{array}{c}\text { Чнсло молочныхъ } \\
\text { коровъ }\end{array}$ & $\begin{array}{l}\text { Число мо- } \\
\text { лоч. коровъ } \\
\text { на } 1000 \approx .\end{array}$ & $\begin{array}{c}\text { Средияя } \\
\text { стонмость одноі } \\
\text { коровы }\end{array}$ \\
\hline 1880 & $\mathrm{x} / 55.155 . .783$ & 12.443 .120 & 248 & 23 д. 27 ц. \\
\hline 1890 & 62.947 .714 & 16.511 .950 & 263 & 22 д. 14 ц. \\
\hline 1990 & 75.451 .000 & 16.292 .000 & 216 & 31 д. 60 ग. \\
\hline 1901 & 76.998 .000 & 16.834 .000 & 219 & 30 д. - \\
\hline 1902 & 78.556 .000 & 16.697 .000 & 212 & 29 д. 23 ц. \\
\hline 1903 & 80.174 .000 & 17.105 .000 & 213 & 30 д. 21 п. \\
\hline 1904 & 81.792 .000 & 17.420 .000 & 211 & 29 д. 21 ц. \\
\hline 1905 & 83.410 .000 & 17.572 .000 & 233 & 27 д. 44 ц. \\
\hline 1906 & 85.028 .000 & 19.794 .000 & 242 & 31 д. - \\
\hline 1907 & 85.646 .000 & 20.968 .000 & 240 & 30 д. 67 І. \\
\hline 1908 & 88.264 .000 & 21.194 .000 & 242 & 30 д. 36 ц. \\
\hline 1909 & 89.882 .000 & 21.720 .000 & 224 & $-\quad-$ \\
\hline 1910 & 91.972 .000 & 20.625 .000 & 224 & 39 д. 97 І. \\
\hline 1911 & 93.118 .000 & 20.823 .000 & 219 & 39 д. 39 ц. \\
\hline 1912 & 94.736 .000 & 20.699 .000 & 213 & 45 д. 02 щ. \\
\hline 1913 & 96.354 .000 & 20.497 .000 & 212 & 53 д. 94 п. \\
\hline 1914 & 97.972 .000 & 20.737 .000 & 212 & 53 д. 94 ц. \\
\hline 1915 & 99.590 .000 & 21.262 .000 & 213 & 55 д. 33 п. \\
\hline 1916 & 101.208 .000 & 21.988 .000 & 217 & 53 д. 90 ц. \\
\hline
\end{tabular}


Ізъ этой таблицы вндно, что за посль̆днія 36 льить населеніе Соединениыхъ Штатцовт возросто на $50 \%$ и вт той же пропордіп увеличнлся молочный скоть.

Стоность дойної коровы почти удвонлась - съ 23 дог. 27 сентовъ въ 1880 году до 53 до.т. 90 ц. въ 1916 году.

Люоропытно отмитпть, тто, сог.асно того же оффиніальнаго источника, юоличество молочныхъ поровъ за время 1905 года піо 1915 г. нъсколько сократплось въ отононенін къ росту населенія въ групп нанбогъе пндустріалыныхъ штатовт, расположенныхъ єъ Съверо-Восточной ойтасти Соед. ІШтатовт, между тьмъ, какъ въ непромышленномъ районь Южно-Западныхъ Штатовъ, гдъ зекледыліе стало развнваться лишь со второй половины 19-го стольтія, съ преобладагщей системой экстенспвнаго хозяйства, наб.юдаетея колоссальное увеличеніе молотнаго скота за 10-ті льтній періодъ.

Напримъръ, въ штатахъ Ньо-Мексиго увелнченіе пронвопло на 240 продептовъ; Аризонь - 132 проц.; Оклахома - 164 проц.

Дия большей полноты ия ясности распреджленія молочнаго скота по шптатамь, мы приводимъ нижестьдующую статнстическуг таб.лиду, показывагоцую развитіе молочнаго скота за время - съ 1905 г.

\section{СТАТИСТИКА МОЛОЧНАГО СКОТА ПО ШТАТАМЪ.}

\section{(ВЂ ТЫСЯЧАХЂ)}

\begin{tabular}{|c|c|c|c|c|}
\hline Назваиіе штатовъ & 1905 & 1915 & Увеличеніе въ $\%$ & Уменьшеніе въ \% \\
\hline Məก๊นธ & 189 & 157 & $\ldots \ldots$ & $17 \%$ \\
\hline Нью-Темшайръ & 130 & 95 & $\ldots \ldots$ & 27 \\
\hline Вермонт' & 285 & 268 & $\ldots \ldots$ & 6 \\
\hline Macaчyceтссь & 191 & 157 & $\ldots \ldots$ & 18 \\
\hline Родъ Ай.тандъ & 25 & 23 & $\ldots \ldots$ & 8 \\
\hline Кониектикуть & 131 & $11 S$ & $\ldots \ldots$ & 10 \\
\hline Нью-Іоркт & 1.722 & 1.509 & $\ldots \ldots$ & 12 \\
\hline Нью-дакерзі & 185 & 146 & $\ldots \ldots$ & 20 \\
\hline Пенеш.тьванія & 1.087 & 943 & $\ldots \ldots$ & 13 \\
\hline Дә.таварь & 35 & 41 & $17 \%$ & \\
\hline Мэрнлендљ & 147 & 177 & 20 & \\
\hline Вирджіннія & 153 & 349 & 128 & \\
\hline
\end{tabular}




\begin{tabular}{|c|c|c|c|c|}
\hline Названіе итгатовъ & 1905 & 1915 & Узеличеніе въ \% & Уменьшеніе въ \% \\
\hline Норть Каролина & 193 & 315 & 63 & \\
\hline Саутеь Каролина & 110 & 185 & 75 & \\
\hline Джорджіа & 277 & 406 & 47 & \\
\hline Флорида & 87 & 133 & 53 & \\
\hline Orailo & 791 & 895 & 13 & \\
\hline Индіана & 548 & 646 & 18 & \\
\hline Иллпнойсь & 995 & 1.007 & 1 & \\
\hline Мнчигань & 550 & 814 & 46 & \\
\hline Висконсинъ & 1.096 & 1.626 & 48 & \\
\hline Мнннесота & 837 & 1.186 & 42 & \\
\hline Айова & 1.336 & 1.337 & 3 & \\
\hline Миссури & 570 & 797 & 40 & \\
\hline Норть Дакота & 144 & 339 & 75 & \\
\hline Саутсь Дакота & 402 & 453 & 13 & \\
\hline Небраска & 669 & 625 & & \\
\hline Канзась & 71 & 726 & $8 \%$ & \\
\hline Кентоки & 287 & 390 & $39^{2}$ & \\
\hline Тенесси & 283 & 355 & 25 & \\
\hline Алабама & 320 & 384 & 67 & \\
\hline Миссисипи & 272 & 434 & 60 & \\
\hline Луцвіана & 166 & 268 & 61 & $\bullet$ \\
\hline Тексась & 838 & 1.086 & 30 & \\
\hline Or.тахома & 187 & 494 & 164 & \\
\hline Арканзасъ & 281 & 387 & 38 & \\
\hline Монтана & 55 & 114 & 107 & \\
\hline Вайомингъ & 20 & 46 & 130 & \\
\hline колорадо & 121 & 205 & 70 & \\
\hline Нью-Мегісико & 20 & 68 & 240 & \\
\hline Арпзона & 14 & 44 & 132 & \\
\hline Юта & 73 & 92 & 26 & \\
\hline Невада & 17 & 24 & 41 & \\
\hline Айдаго & 60 & 120 & 100 & \\
\hline Вашингтонъ & 159 & 253 & 59 & \\
\hline Орегонт & 139 & 210 & 51 & \\
\hline Калпфорнія & 355 & 541 & 52 & \\
\hline Во всьхъ ит. & 17.572 & 21.262 & $20.9 \%$ & \\
\hline
\end{tabular}


Разсомтримъ теперь количественне распреды.леніе молочнаго скота по отдыльнымъ хозлйствамъ въ различныхъ зем.тедњ.тьческихъ районахъ.

По даннымъ генера.тьнй переписки населенія 1910 года:

\begin{tabular}{|c|c|c|c|c|c|c|}
\hline \multirow[t]{2}{*}{ Р а й оны } & & \multicolumn{3}{|c|}{$\begin{array}{l}\text { Среднее тисло мо- } \\
\text { дочныхъ горовт на } \\
1 \text { ферму (1909 г.) }\end{array}$} & \multicolumn{2}{|c|}{$\begin{array}{c}\text { Среднее процзводство } \\
\text { молока на } 1 \text { корову } \\
\text { въ галонахъ }\end{array}$} \\
\hline & & & & & 1909 & 1899 \\
\hline \multirow{2}{*}{\multicolumn{2}{|c|}{$\begin{array}{l}\text { Новая Англія } \\
\text { Средне-Атлантическіе Штаты }\end{array}$}} & & 3.8 & & 476 & 548 \\
\hline & & & 6.1 & & 490 & 514 \\
\hline \multicolumn{2}{|c|}{ Іентр. С६в. Восточн. Шататы } & & 4.0 & & 410 & 487 \\
\hline \multicolumn{2}{|l|}{ Западные Штаты } & & 4.9 & & 325 & 371 \\
\hline Югт (Зап. района) & OTb & 1.9 до & 3.1 & & $232-286$ & $240-285$ \\
\hline Западъ (2 района) & OTъ & 4.7 до & 5.1 & 3 & $39-475$ & $334-470$ \\
\hline Среднее для Соед. II & & & 3.8 & & 362 & 424 \\
\hline
\end{tabular}

Отсюда видно, что въ ШІтатахъ съ интенспвной снстеної сельскагс хозяйетва мы наблюдаемъ значительно болье групныя молочныя хозяйства, чвмъ во всьхъ оста.тьныхъ областяхђ экстенсивнаго вемледълія.

Районы самыхъ мелкихъ (по количеству обрабатываемой земли суть районы самыхъ крупныхъ молочныхъ хозяйствъ.

Этоть фапть, пмъетъ громадное значеніе, ибо молочное хозяйство, какъ пзвъстно, развивается всего быстрђе въ подгородныхъ мыстностях'ъ и въ странахъ особенно развитої промышленності. Статистика Даніи, Германіи и Швейцаріи показывають намъ ту же растущую конпентрацію молочнаго скота. 


\section{ЭКОНОМИЧЕСКІЕ ФАКТОРЫ МОЛОЧНАГО ХОЗЯЙСТА.}

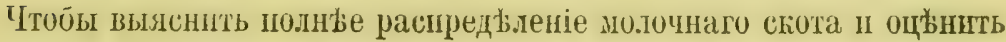

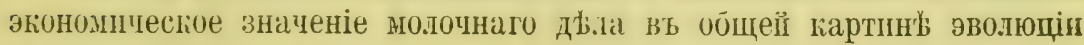
Амерпканскаго вемледы.лія - мы разсмотрит статпстическія данныя по основным' группамъ хозяйствъ, в.тадыюпцхъ молочнымъ скотомъ, въ отношеніп къ размьрамъ земельныхъ в.ладъній:

Грулиты фермъ съ земельнымъ владвні мъ

\section{До 20 акровъ}

Отъ 20 до 49 акр.

" 50,99 ,

" 100,174,

, 175,499,

, 500,999,

, 1000 „ і болье

Всъ Соөдин. ШІтаты

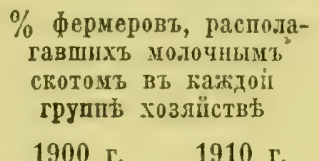

1900 r. $\quad 1910 \mathrm{r}$.

$49.5 \% \quad 52.9$

65.09

71.02

84.1

88.9

87.1

89.8

92.6

90.3

82.9

93.5

86.6

$78.7 \% \quad 80.8$

\section{Увелпченіе или} уменьпеніе

Плюсь $3.4 \%$

, 3.4

". $\quad 3.0$

" 0.9

, 0.9

" 0.7

" 3.1

Плюс⿰ $2.1 \%$

Мы видимъ, такнмъ образомт, чго нашболыній проценть фермт, располагающихъ молочнымъ скотомъ, прнходится на групныя фермы (93.5\%) съ земельными владжніпи вт 175-499 акровъ.

За деслтильтіе съ 1900 по 1910 годъ всего болье увеличились мелгія фермы, дерлація молочныхъ торовь, затьиъ Латпфунддіи, далье среднія фермы.

Уменьшился процентъ фермъ съ молочныпт скотомъ у групныхъ хозяевъ съ 500-999 агровъ земли.

Въ общемъ, здъсьь получаетсл, повидпмому, выпгрышъ мелкаго вемлевладыльца. Напомнимъ, однаго, что в.тадыніе мо.точнымъ скотомъ имъеть двоякое значеніе вт сельсгомь хозяйствђ : сь одной стороны оно можеть означать общее повышеніе благосостоянія пा улуџшенія условії пптанія, съ другой стороны - Iг чаще - оно ољпатаеть

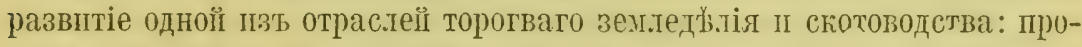
пзводетво молока на продажу въ города іп промышленные центры. 
Фермы этого рода, „мо.точныя фермы“, выдћ.лены амерпканскими статистиками въ особую группу по г.тавонму источнику дохода. Әта групша отличается количествомъ выработанної вемли и всей земли ниже средняго при суммь пронзводсгва выше средняго, прі употребленін наемнаго труда - вдвое выше средняго, по расчету на одинь акрь земли.

Увеличеніе роста мелкихъ фермъ въ молочномъ хозлійствы очень легко можеть означать и, навњрное, означаеть рость капиталистическихъ молочныхъ фермъ на мелкихъ участкахъ вемли, работаюцихь всецьло на потребнтельскій рынокъ или для обс.тужнванія молочной индустріи - пронзводство масла, сыра и другихъ продуютовъ.

Вотъ, для параллели, данныя о концептрацін скота въ Америкьи.

$\mathrm{P} \mathbf{2}$ หั 0 ถั แ

CAвер:

Юrs

Западъ

Среднес количество модочныхт коровъ на 1 ферму 1900 r. 1910 r.

$\begin{array}{cccc}4.8 & 5.3 & \text { п.люсъ } & 0.5 \\ 2.3 & 2.4 & , & 0.1 \\ 5.0 & 5.2 & , & \end{array}$

Мы видимъ, что Съверъ всего болье богатъ молочнымъ скотомъ, увелниль свое богатство.

Теперь просльдимъ, какъ распредълилось это увеличеніе между грушами

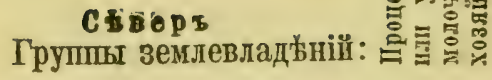

До 20 акр. земли минусъ $4 \%$ Оть 20 до 40 arp. " $3 \%$ , 50,99 , илюсъ $9 \%$ " $100,174 \quad, \quad, \quad 14 \%$ " $175,499 \quad, \quad, \quad 18 \%$ " $500,999 \quad$ ",$\quad 29 \%$ "1000 ии болье , , " $18 \%$
Увемиченіе иап уменьтеяіе числа фермт

$10 \%$ увелич. числа ферм'

$12 \%$ уменьш. , , $7.3 \% \quad, \quad, \quad$,

$2.2 \%$ увелич. ", , $12.7 \% \quad, \quad, \quad$, $40.4 \% \quad, \quad, \quad$, $16.4 \% \quad " \quad " \quad$,

0бщее увеличеніе въ среднем 14\%

$63 \%$ увелич. писла фермь 


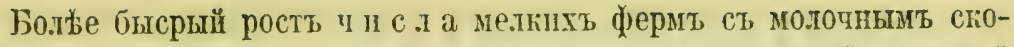
томъ (показано въ предыдущей таблиц') не іюмьшало болье быстрой в 0 н ц е н т р а ц і и его въ грунныхъ хозяйстьахъ. Этоть процессъ концентраціи и увеличенія молочної промышлености находится въ полномъ соотвђтствін съ обцим строемт Амернанскаго земледылія, развиваюцагося при условіяхт тинчнаго папнтализма.

Торгово-промыпленное значеніе молочнаго дъ.ла въ Соединенныхъ Штатахъ увеличнвается съ каждым годомь, привлекая трудь и капи-

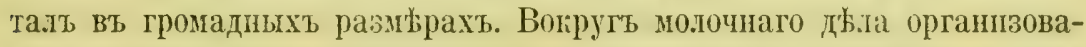
дись спльныя финасовыл корпорацін, органичесги связаниця съ нимь и контролирующія рбшителын всь фазы пропзводства и сбыта молока и молочныхт продугтовъ на внутреннемь и заграничноъ рынкахъ.

Производсгво молочныхъ гродуктовт въ Соединенныхъ Штатахъ въ 1917 г. распредыляетсл сльдуюшцмь образомъ:

Пронзводство всего модока 84.611.350 англійскихъ фуунтовъ.

Изъ этого количества употреблялось въ видь:

\begin{tabular}{|c|c|c|c|c|}
\hline Жидкаго молока & 36.500 .000 & англійск & фунт. & $43 \%$ \\
\hline Масла & 34.633 .853 & , & " & $41 \%$ \\
\hline Chrpa & 4.200 .000 & " & "’ & $5 \%$ \\
\hline Конденс. молоко & 2.437 .500 & " & " & $2.9 \%$ \\
\hline Мороженное & 3.150 .000 & " & - & $3.7 \%$ \\
\hline Телячье молоко & 3.166 .000 & , & " & 4.3 \\
\hline
\end{tabular}

Эта таблица показываетъ распред火火.еніе жндкаго молока, поступающаго отъ фермера на рынокъ, причемъ процентъ столоваго молока, потребляемаго въ жидкомъ видт, составляеть- $43.1 \%$ и приблизительво столько же молока ( $41 \%$ ) поступаеть на пронзводство масла.

$32 \%$ насеелнія Соединенныгъ Штатовъ занято земледыліенъ. Если все населеніе въ настоящее время исчисляется въ 105.000 .000 то 33.600 .000 человъкъ живеть на фернахъ.

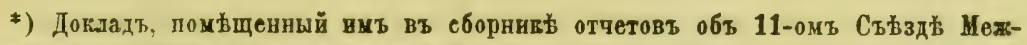
дународнаго Общества Провзводитедей Модока, состоявпехся въ पпкаго въ декабры 1918 года. 
Статистическое Бгоро прп Федеральнот, Правптельств. опредь.яеть, что одна треть всего земледжльчесгаго пасе.енія ванята молочнымъ хозяйствомт, тто состав.яеть 11.000 .000 челов"ькт іп, сверх'ь того, около 500.000 человъћ обслуживають транспортировку и распредыленіе молока и молочныхъ продугтовъ в’ь городахъ.

Стонмость сельсго-хозяйственныхъ продуғтовъ, пропзведенныхъ въ 1918 году, сог.тасно годоваго отчета Минстра Земледълія:

Пр о д укты

Кукуруза

Mo.rorio

Пиенцца

Свинина

Овест,

Скотское молоко

Остальн. продукты

И Т 0 Г 0
С у M M 2

4.563.668.000 долларовъ

$2.360 .120 .000 \quad$ "

$2.177 .810 .000 \quad$,

1.848.000.000 ,

1.274.296.510 " ,

828.750 .000$,

11.647.325.810 ,

Какъ видно пзъ, вышеприведенної табллщы, пронвводство молока, въ ряду другихь главнбйшихь предметовъ сельско-хозяйственной промышленности въ отношеніи своеї рыночной стопмости, занимаетъ вт0рое м'всто и выражаетсл въ сумм' - 2.360.120.000 долларовъ.

Главнбйпее вліяніе на развптіе молочнаго хозяйства оказала зи посльъніе годы война, когда всњ Европейскія государства сн.їнэ увеличили спросъ на американскомъ рынге на масло, сыръ п тонденспрованное молоко *).

Бюро Пищевої Адмнистраціп прп Федеральном Правительствґ

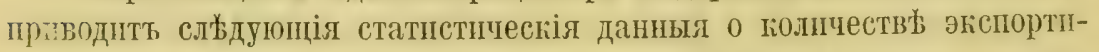
рованныхъ молочныхъ продуктовъ только въ Союзныя Страны за время Съ 1911 по 1918 г. т.

*) См. С. В. Гейманъ. Іролзводетво Сухого и Сгущениаго молога въ Америка́. Ньто-Іоркъ, 1919 г. 


\section{ВЫВ03ъ Въ СОЮЗНЫЯ ГОСУДАРСТВА.}

1911-1912 r.г. 1912-1913 г.r. 1913-1814 г.г. 1914-1915 г.г.

\begin{tabular}{lrrrr}
\hline & Фунтовъ & \multicolumn{1}{c}{ Фунтовт } & \multicolumn{1}{c}{ Фунтовъ } & \multicolumn{1}{c}{ Фунтовъ } \\
Сыръ & 3.823 .855 & 638.001 & 550.608 & 50.562 .339 \\
Масло & 1.451 .995 & 60 & 721.520 & 3.336 .565 \\
Конденс. молоко & $\mathbf{1 . 2 0 2 . 0 0 7}$ & 9.715 & 342 & 7.373 .881
\end{tabular}

1915-1916 г.r. $1916-1917$ г.г. $1917-1918$ г.г.

\begin{tabular}{lrrr}
\hline & Фунтовъ & Фунтовъ & Фунтовъ \\
Сыръ & 38.080 .351 & 55.040 .366 & 42.603 .336 \\
Насло & 6.325 .098 & 20.959 .016 & 15.898 .511 \\
Конденс. молоко & 95.455 .09 .4 & 148.157 .801 & 502.240 .893
\end{tabular}

Енегодниъ Департамента Зем.тедніл Соединенныхъ Штатовъ Сьверной Америки даеть прибливптельно ть же данныл, показывающія колоссальныц рость вывоза заграницу конденспрованнаго мохока, масла и сыра за тоть жке періодт времени (1915-1917 г.г.) въ сраввеніи съ предшествующими годами.

\section{ЭКСПОРТЪ МОЛОЧНЫХЪ ПРОДУКТОВЪ СОЕД. ШТАТОВЪ.}

$$
\text { (Съ 1911-1917 г.г.) }
$$

(Ежегодникъ Департамента Земледълія за 1911-1917 г.г.)

$$
1911 \text { г. } 1912 \text { г. } 1913 \text { г. }
$$

Масло

Сырь

Конденс. молоко

Остальные

модочн. продукты

1.059.432 дол.

2.288 .279 "

936.605 "
1.468 .235 дол.

848.035 ,

1.651 .879 ,

244.913

1916 г.
872.804 дол. 441.186 ,

1.432 .858 ,

474.055 ,

1917 г.

Масло

Сырь

Конденс. молоко

1915 r.

Друіе молочные

2.392 .480 дол.

8.463.174,

3.590 .105 дол.

7.430 .089

8.749 .170 дол.

3.066 .642

12.712 .952

$"$

15.244.364,

25.129 .983 "

продукты

343.583 ,

524.426

285.467 
Не меньшее значеніе пяъла война въ отноеніи установленія стонмости молока на мыстномъ рынке.

Изученіе мо.ючныхъ цынъ покаэцваетъ, что подъем нхъ хотя и варінруеть вт разныхъ мьстахъ Соеднненныхъь ІІтатовъ, однако, отличаетея болынеї уетойчнвостью и эначнтельно отстаеть оть вздорожапія другихъ продуктопъ сельско-ховяйственной промышленностн первой необходнмостн, кащъ это съ очевндностыо видно изъ нижіесльдующей таблицы роста рыночныхъ цынъ на нью-іоркской биржъ въ ни)ябрез мъслць съ 1914 по 1918 г.г.:

ПОВЫПЕНІЕ ЩЪН НА ПРЕДМЕТЫ ПЕРВОЙ НЕОБХОДИМОСТИ. (Нью-іоргскій болтетень цънъ сқ ноября 1914 г. по ноябрь 1918 г.)

\section{$1914 \mathrm{r}$.}

Яйца (дюжина)

Кукуруза (бушель)

Сахарь (100 фо.)

Мясо (фунть)

Сыръ (фунть)

Macıo (фунть)

Молоко (бутылка)
23 цента

7266

3 д. 32 "

18 центовъ

14 "

27 6

09 6
1918 r.

85 центовъ

1 д. 72 цента

9 д. 35 центов'

48 "6

$46 \quad 6$

77 6

17 "
$\% \%$

269

139

181

166

128

226

88

Въ гонечномт итогъ, если взять ныноторыя цыны пнщевыхъ прюдуктовъ въ птату Нью-Іоркъ за рремл еъ 15-го іюля 1913 года пю 15-ое іюля 1918 года, то оказывается, что жіры вздорожали на $106 \%$, мука на $103 \%$, пукуруза на $123 \%$; между ть̆мъ мо.локо вздорожало лишь на $47 \%$ за тоть же періодь времени. 


\section{СТОИМОСТЬ ПРОИЗВОДСТВА МОЛОКА И ИЗМЬНЕНІЕ мОЛОЧнЫХъ ЦБНъ НА РЫнКБ.}

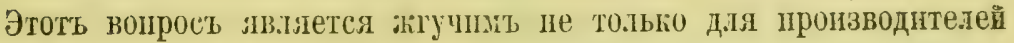
молока, но равно иг дия его распредђылелеиі-посредниковъ, снабюающнхъ массоваго потребителя въ прунныхъ городскікъ центрахъ.

Все молочное хозлйство регушруется въ Соед. Штатахъ прниципами свободной конкуренціп, и молочныз цьны, естественно, претерп'вваютъ всякія вліянія торгово-промышленной жизни страны, находясь съ посльдней въ полной ортанической связи.

Много бы.то пронвведено пошытокъ различными заинтересованными учрежденіями и частними изетьодователями установить средні: издержки фермера на производство молока.

Вт этомъ отношеніи напорошьій интересъ заслуживаютъ много"исленные опыты, пропведениые проф. Корнельскаго уншверситета, Г. Ф. Варреномъ, который скоми́ннроваль статистическія данныя иљъ различныхъ агрикультрныхъ об.хастей Соединенныхъ Ітатовъ н по.уучиль ншжесльдующую формулу, представляюпую дотевое соотношеніе вормовыхъ продуітовъ, необходимыхъ для питанія молочнаго скота, входящихъ въ стомость пропзводства 100 фуптовт молока.

\section{КОЛИЧЕСТВО ПИЩЕВЫХЪ ПРОДУКТОВЪ, НЕОБХОДИМЫХЪ ДЛЯ ПРОИЗВОДСТВА 100 ФУНТОВЪ МОЛОКА.}

33.79 фунта зерна, 40.03 фунта сћна, 10.08 фунта сухого фуража, 92.02 фунта ризют июъ кормовыхъ травъ, 8.03 фунта разлнинато рода кормовыхт притравт, 3.02 часа пабочей жнвой силы.

Стопмость вышеуказаняыхъ пропорцій кормовыхъ продуктовъ въ

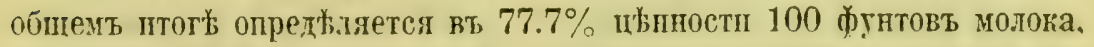
остальные $20.3 \%$ составтяютт, накталныя пвдерікти по оптать по по- 
щенія для горовъ, пости.очной травы въ стой.тахъ, страхованія ссота оть больвнеї и старости, уходт за ними, храненіе молока, ледъ и прочеe.

Если взять формулу проф. Г. Ф. Варрена, принятую теперь прагтической агрономіей и сельско-хозяйственной экономикой, и приложить ее къ ц'לнамъ пицевыхъ продуктовъ, употребляемыхъ для молочнаго сгота въ октябрб 1914 г. І октябрб 1918 г., то стоимость ихъ для проивводства 100 фунтовъ молока съ содержаніень жира въ $3.8 \%$ представится въ сльдующемъ видж:

\section{СТОИМОСТЬ ПРОИЗВОДСТВА 100 ФУНТОВЬ МОЛОКА}

(Съ средниъ содержаніемъ молочнаго жира въ $3.8 \%$ ):

Въ 1914 г.

Зерно

Съно пи прочій сухой кормъ....... 0.3025

Мжспво нзъ ржзкі кормовыхъ травъ 0.2508 Питательныя приправы.......... 0.4177

Стонмость ватраченной работы.... 0.6048

$$
2.0888 \text { "6 }
$$$$
\text { Стомиость кварты молока } 0.454 \text { “ }
$$

Въ 1918 г. 1.0261 п. 0.4295 " 0.4137 “ 0.7192 " 1.0087 "6

Изъ этой таблпц, такимъ образомт, сльвдеть, что пропвводство 100 фунтовъ молока въ 1914 г. обходилось фермеру въ 2 д. 59 цент. или 0.45 цента за одну кварту молога въ 1914 году і 0.78 цента въ 1918 году. Это возрастаніө стопмості прогвводства молока и есть прямої результать войны, вызғавпеї вздорожаніе продовольствія Іі стонмости рабочнхъ руюъ во всьхъ областяхъ Соединенныхъ IIIтатовъ.

Въ соотвътствіп ст возрастаніемъ цынъ на предметы пропзводства молока, точно также отытуается повышеніе стопмості накладныхъ из-

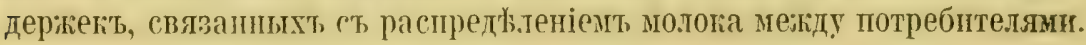

Назначениая иьо-іорнспит городскимт самоуправлепіемъ спеціальная томшесія по обелтдованію вопроса о снабженіи мологомт, го- 
родского населенія - собрала среди молочныхъ помпаній весьма лобопытныя данныл, позволяющія суднть о разыјр's нагладныхъ расходовъ этихъ помпаній, снабжающихъ молокомъ Ньо-Іоркскаго потребцте.я:

1915 г.

1918 г.

1. Перевозка молока отъ концентрапіон. станцін на жв. д. до городск. мо.очн. депо 0.0093 цента

0.0120 ц.

2. Общіе хозяйствен. расходы компаніп по веденію дыла.

0.0120 цент.

0.0260 ц.

3. Поставка молока къ местонительству потребителл

0.0238 цент.

0.0404 ц.

4. Администрація

0.0032 цент.

0.0040 ц.

В С Е Г 0 на 1 кв.-0.0483 цент.

0.0824 п.

За четыре года Европейской войны расходы молочнаго посредника, въ впдъ крупныхъ мо.точныхъ компаній, увеличились на 1 кварту молока съ 0.0483 цента до 0.824 ц., т. е. почти на $50 \%$. Сюда вклюqается повышенная оплата рабочпхт и служіебнаго персонала, вздорожаніе молочной посуды, машинъ, стропте.пьныхъ матеріаловъ, спеціальныя об.лояенія военнаго времени, страховка и прочее.

Значптельнымъ факторомъ, вліяющимъ на подъемь молочныхъ цьнъ - являются пздержки, связанныя съ улучшеніем санитарныхъ условії процдодства молока, которыя ложатся тяжелымъ бременемъ на фермера, и безъ того зависимаго во всњхъ отношеніяхъ отъ молочныхъ-посреднических'ь 'трестовъ.

Государственный Денартаментъ Зем.тедъ.тіл сшпгаетъ, *) тто экстренные расходы на санитарпзацію мо.очной промышленности и улучшеніе качества мотока (тубергулезное испытаніе коровъ, пастерпзацін п прочее), вт общемъ увеличиваеть стопмость одной бутылки модока на 2 цента.

Д-р'ъ Нортъ псчисляеть эті расходы въ $1-1 / 2$ цента.

Пастерпзапія одного га.тона молока д.я города Чикаго исчнсля-

*) "Tle Modern Milk Problem," by J. Scott McNutt, 1917, Vol. IV, p. 637. 
етсл въ $1-1 / 3$ цента для прупныхъ молочныхъ депо и въ 0.85 цента для нелишх。 *)

Почти невозможно установить съ точностью пздержки фермера на прогзводство молока, т. $к$. въ этоть учеть трудно включить всь индивидуальныя особенности методовъ веденія хозяйства II разнообразіе мыстныхъ условій. За то легче учитываются расходы молочныхъ компаній вт проце́сеъ́ закупки пг сбыта молока.

Земледыльческій Коллэдж въ птать Массачусетсь пронзвелт обсльдованіе 42-хъ молочныхъ распредълительныхъ депо въ 6 групныхъ городахъ п получиль слььдующе результаты для опредъғенія расходов'ь на снабженіе нолокомъ городского населенія:

\section{АНАЛИЗЪ ОБЩЕЙ СТОИМОСТИ РАСХОДОВЪ НА ПОСТАВНУ ОДНОЙ КВАРТЫ МОЛОКА.}

1. Амортизація оборудованія молочнаго депо (живой иг мертвый пнвентарь ............... 016 ц. пли $5.69 \%$

Содержаніе депо пг администрацін. (Коритеніе лошадей, почин-

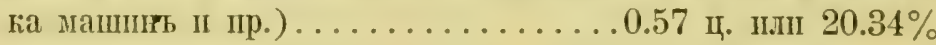

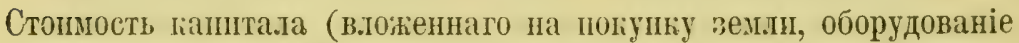
завода, пріобротеніе .онадей и пр.) находящагося въ работн .................... 0.48 п. пाли $17.6 \%$

Рента, страхованіе, ледъ, ломъ булылокт, утечка мөлока, заработанная п.тата рабочпм'ь (не менбе 25 центовъ вь чась) ..................... п. $56.91 \%$

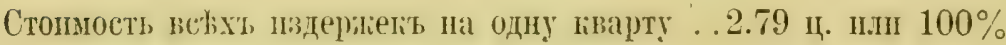

Раскладывая этоть птогь на операпіонио-распредъ.лительную работу молочнаго депо в'ь огношеніп одной пварты молока при рознгчной

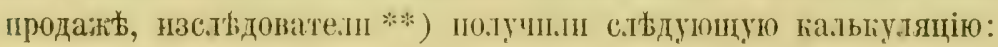

*) E. O. Jordan, Transl. XV, Internal Congress in Hygiene and Demography, Volume IV, page 637.

**) A. E. Canec \& R. H. Ferguson: "The cost of distributing milk in six towns of Massachussets, 1917. 


\section{ПОДГОТОВКА МОЛОКА.}

1. Подвозъ молока па концентраціонныя станцін въ провнндік.

2. Перевозка по жельзиымт дорогамт въ городъ.

3. Изсльдованіе, пастеривація, разливка по бутылкамъ и храненіе въ холодильникахъ ......... 0.758 ц., или $27.19 \%$.

\section{Развозна молока среди городскихъ потребителей.}

1. Прн погрузнъ въ среднемъ 165 бутылољь на 1 фургонъ

1.528 ц., нли $55.14 \%$.

2. Накладные расходы ............ 0.492 ц., или $17.67 \%$.

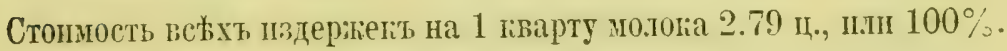

Прп оптовой поставен молока расходы сокращаютея на полтцента на бутылюу.

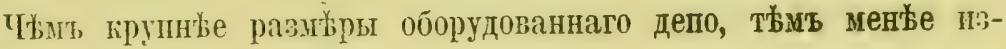
дернки на поставгу молока.

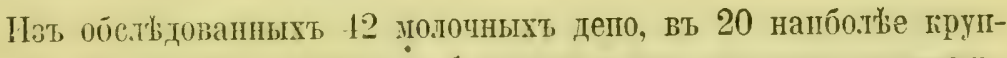
ныхъ предпріятіяхт пздержки на 1 кварту нолока оказались наниеньшими-1.64 цента; вт, депо, поставляющія молоко въ неболышихъ размърахъ, эті расходы увеличнваются до 2.4 пента.

Ана.лізъ г.г. Пэнса й Фергюсона съ ничтожными варілціяли поттверждается ана.огпчным пзученіянь въ другихь итатахъ НьюИнг.тандт, 2.5 цента) *), іл поэтому имт можно руководствоваться

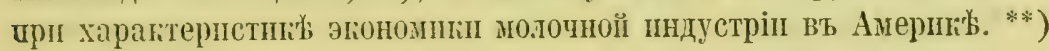

Вт гонечномт птогы составныя части рыночной стопмости одной

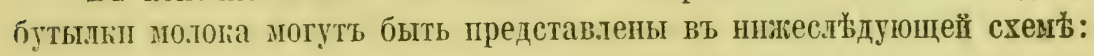

*) Boston Chamber of Commerce. Special Report, 1915.

**) Mr. Thompson-_"Cost of Producing Milk on 174 farms in Dalawars County, N. Y." 


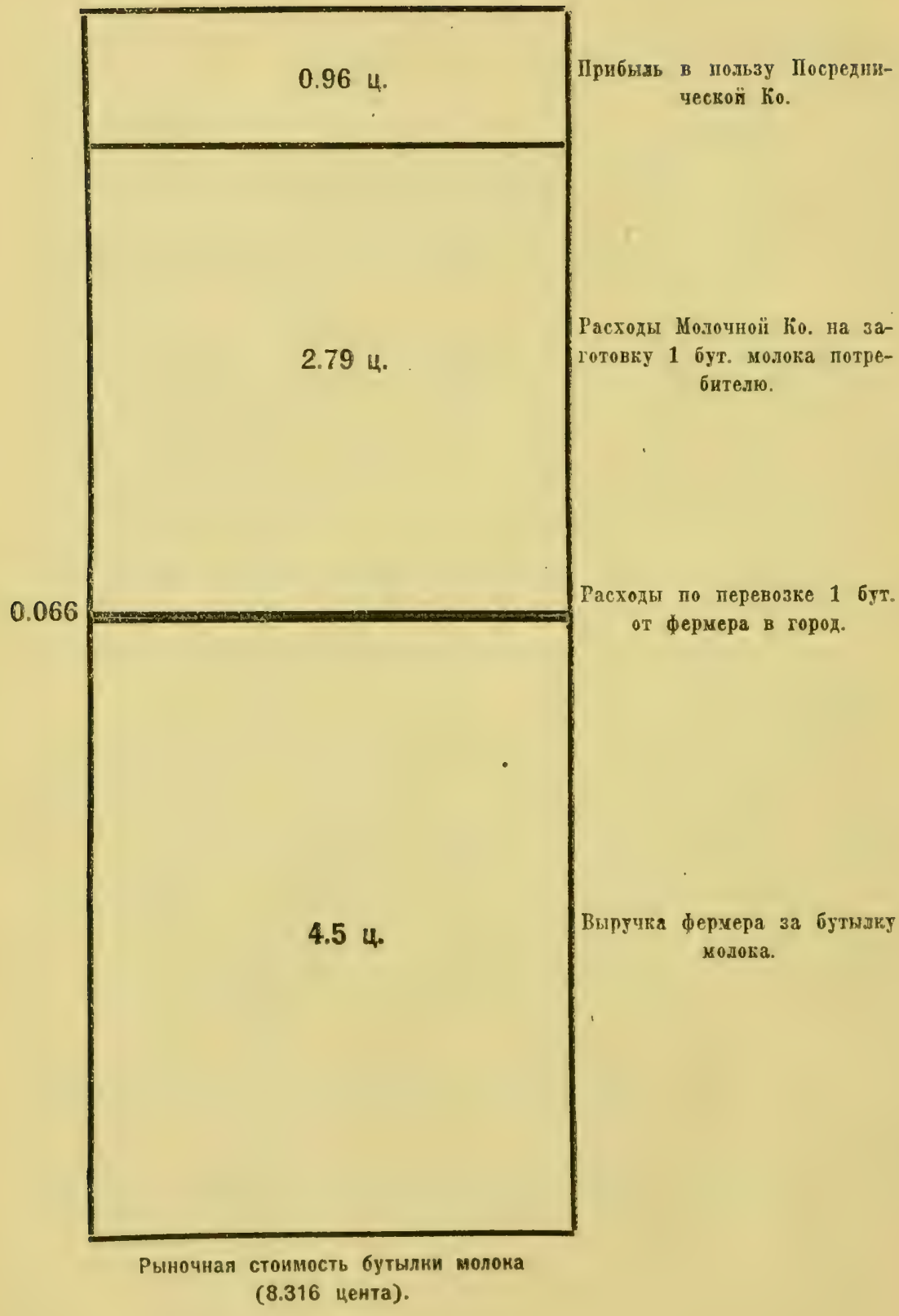




\section{ОРГАНИЗАЦІЯ СБЫТА МОЛОКА.}

Наповолье трудную проблему, которої запнтересованы, не столько посредническо-молочныл қонпаніи, скольго пронзводители-ф̆ермера и потребители-состав.леть вопрось о разницы между цынами на молопо у фермера-пропвводителя и на рынкб, другими с.товами: какая доля рыночной стопмости молока остается въ пользу крупныхъ молочно-посредническихь компаній.

Въ этомъ отношенін мы воспользуенся весьма циннымъ матеріаломъ, представлениымъ различными снеціалистами въ многочисленныхъ докладахъ на ежегодныхъ молочныхъ съъздахъ при Ныо-Іорћскомъ Молочномъ Комитеть, въ поторыхъ участвують представители общественныхъ и санитарно-медицинскихъ учрежденій, а равно и производите.лі п омлочные посреднипи со всего Нью-Іоргскаго Штата.

Статистическія свъдъънія по этому вопросу скомбннированы мною за тоть же четырехльтній періодъ, въ теченіе котораго мы обсльдуемъ молочное хозяйство въ Соединенныхъ Штатахъ съ той цыљлью, чтобы просльдить измьненіе рыночныхъ цьнъъ на молоко при условіяхъ неноржальной хозяйственной коньюнктуры съ 1915 года до оконтанія Европейской войны.

Всъ Амернканскіе спеціалисты по молощному дызу единодупно отмьччають тотъ фактъ, что крупныя молочныя компанін, монополизнровавшія все дъ.ло снабженія молокомъ городовъ, поставили въ полную безпомощность фермера и городского потребителя въ отношеніи рыночныхъ цьньъ на молоко.

Если мы разсмотримъ нпжесльидующую таблицу, опуб.ликованную Һ-ромъ Норть, легко замьтить, что молочныя компаніи отрываютъ .тьвиную долю рыночной стонмости молога, почті плтьдесять процентовъ, п съ больпимъ избыткомъ погрываютъ операдіонныя издержігіп нолочно-распредьлительныхъ депо, какъ это съ очевидностью вытекаетъ пъъ приведенныхъ нами ранъе данныхъ. 
ЦちНЫ ЗА 100 КВАРТЪ МОЛОКА НА НЬЮ-ІОРКСКОМЪ РЫНКБ.

(В розничной гродажы).

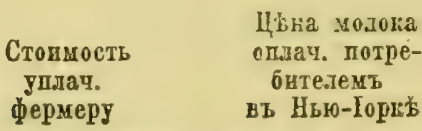

Разицца поступающая въ подьзу посредника

1912 г. 3 д. 57 д. *) 8 д. 9 ц. въ среднемъ

(съ 1911-15 r.)

1913 г. 3 д. 85 ц. ***)

1914 г. 3 д. 80 ц.

1915 г. 3 д. 66 ц. $\quad 9$ д.

1916 г. 3 д. 98 ц. 9 д. 33 цента

5 до.. 34 ц.

1917 г. 5 д. 82 ц. 11 д. 96 центовъ

5 дол. 35 ц.

1918 г. 7 д. 13 ц. 14 д. 50 ценговъ

6 дол. 14 ц.

7 до.І. 28 щ.

Не для ного не секреть, что посредническая дултгельность мо.очныхъ трэстовъ слипкомъ дорого оп:тачивается обынми сторонами: городсніль потребптелемъ и фермеромъ. Это обстоятельство ил вызва.ло всеопцее нареканіе и недовольство въ обществъ п петатп протнвъ молочныхт компаній.

Рядъ городскихъ самоуправ.теній и обпественныхь дынятелей (между прочнуь, соціа.пистическій вождь джінь (парго), разрабатывають въ настояцее преми вопросъ о мунициалнзаціи мо.10чної промыш.лениости, псходя пзт тьхъ же соображеній, поторыл лег.и въ основу му-

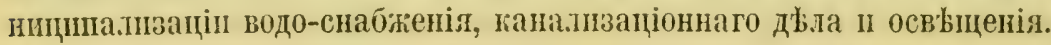

Вт несскольних небольшихь городғахъ, канъ то Дноймстаунь (шт. Н. І.), Бруглинь шит. Массачусетсъ; Іал10-Алт--Калифорнія, уже пражтиески проведена муницигализація моточнаго снабженія и результаты оказались больше чьмь удов.тетворительны.

Нниціатива в'ь реорганизаціп со́ыта молока иеходить, главньм' образомъ, со стороны фермеровъ до послждняго времени рбшительно

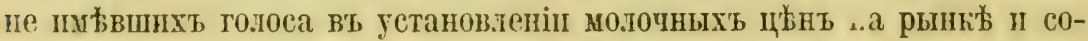
вершенио изолированныхт оть городского потребителя.

Просматрпвая періодпческія пзданія посвяценныя молочному ды-

") "Weekly News" Letter to Correspondents, Jan. 20 and April 28, 1915.

**i) Bulletin of Department of Agrieulture, Washington, 1919. 


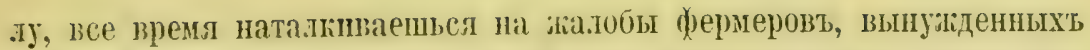

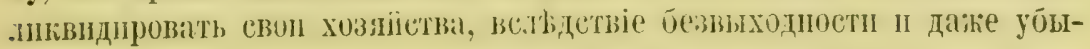
точности Шхь.

Департаменть Земледъ.тія Соединенныхъ Штатовъ топорпть сл'ьдугшее въ одномъ изт свонх бюлтетеней:

.Тольіо одна треть молочныхт піоровт въ Нью-Торкестомт, птт. содеринтся сь прноблы".

„Если вћрно это для Нью-Іоркскаго штата то, по всеї вйроятпиеті, нодобнее явтеніс паб.тюдаетея во многихъ другихъ пітаTaxi" *).

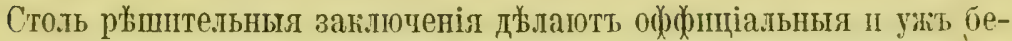

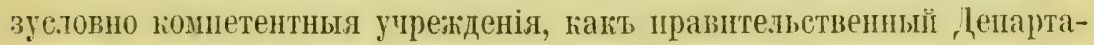
менть Земледыл.

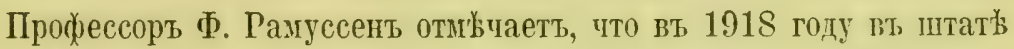
Нью-Гэмпшайрь оольнинство фермеров'ь продавало молого с"ь, уо̆тรом'b.

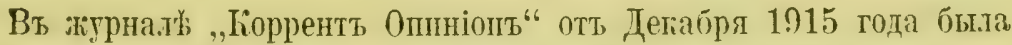
напечатана статья подъ загтавіемъ - „Торгов.л мологомт - гань

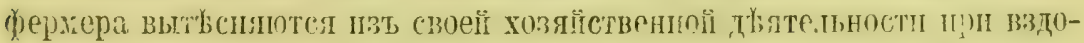
рожанін жнзин".

Бездоходность молочныхъ фермь объясняется тремя прпитнам:

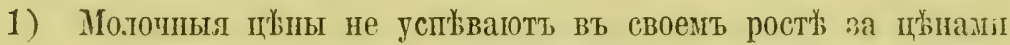
на. предметы первой пеобходимости общаго потрео̆ленія, (какъ это мы указали въ предыдущихъ таблпцахъ),

2) Вздорожаніе рабочнхъ рукъ.

3) Полное отсутствіе контакта между потребителемъ и фермеромь находлщимся въ зависпости отт посредническихъ мо.

Въ то время какъ молочныя пұъны въ розничной торговль возросли па $32 \%$, за пергод форуажт для скота и стопмость рабочпхъ ругъ уве.личились иа 65\%, съ 1890 по 1918 г.г.

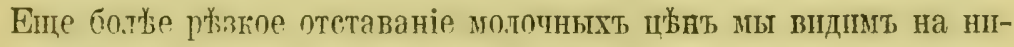

*) Дия. С. Макъ-Нэгтт, указ. сопиненіе ст. 123. 


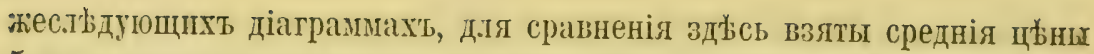
5-тіг главныхъ предметовъ продовольствія: свъжія яйца, партофель, безкостное мясо, свпное сало и мука.

Крнвая, вычерченная на діаграммъ, охватываетъ періодъ времепи съ 1890 года по 1915 годъ.

Вышеуказанныя условія молочнаго фермерства и вызвали къ дыятельности различные виды кооператнвовъ въ об.ласти событа мо.тока, поставпвшіе себъ цыльью освобожденіе отъ эксплоатаціп фермера молочными посредниками, въ лиц'ь си.льныхъ финасовыхъ горпорацій.

Размюры настоящей работы не позво.тяоть намъ подробно остановиться на описанін Молочныхъ Ііооперативовт, поэтому л коснусь лишь немногихъ, заслунивающихъ нанбольпій пнтересъ.

Кооперативное движеніе въ молочномъ дъъљ (я не касаюсь кооперативнаго сырованія і маслодылія) начпнаеть появляться всего только съ 1911 года.

Первый кооператпвъ органнзовалсл въ городъ Риверсайдъ въ Калифорнін, для пастернзаціи молога и непосредственнаго снабженія молокомъ городского населенія. Фермера собрали складочный капиталк въ 20.000 долларовъ путемъ размыщенія паевъ, исключительно среди прогвводителеї молога, живущихъ въ окрестностяхъ города Риверсайдъ. Этихъ денегъ бы.ло достаточно для оборудованія Пастерпзаціоннаго депо, погупки машинь и пр.

Д-ръ Г. Е. Тукеръ, инспегторъ Бюро Общественнаго Здоровья города Риверсайда, пишеть сльдующее объ этомъ юоперативъ:

„Въ Іюль' 1910 г. розннчная цънна на молого была 81/4 цента за кварту еъ $3-4 \frac{1}{2} \%$ содержнмости молочнаго жира.

„Со вреемни органиваціи молочнаго піоператива, снабжаюцаг! молокомь терезт свое пастернзаціонне депо все населеніе города, цьна на молоко немедленно опустилась до 6.2/3 цента за кварту, сь содержаніемь молочнаго жира отъ $4.2 \%$ до $4.5 \%$ п въ тапой цвнь продолжаеть оставаться до сего дня".

(Бю.летень, Калифорнія ІІт., Билдиць ойь Ге.тт, Май 1916 г.) 


\section{ЛИГА МОЛОЧНО-ФАРМЕРСКИХЪ ОРГАНИЗАЦІЙ.}

(The Dairymen's League Organization in New York).

Въ 1915 году пробуждается спльне двњкеніе мо.точныхъ фермеровъ противт необузданныхъ аппетитовъ всесильныхъ молочныхт трустовт. Эта борьба прнниметь форму организованнаго двпніенія въ теченіе 4-хт лытней пампаніп и да.та столь блестлиіе результаты, что пзмьнила корениым образомь всю торгов0-промынленную сптуадіг мо.точнаго дъ.та во всей стран'ь.

Во многпхъ атрарныхъ районахъ давно улке существовали мелкія

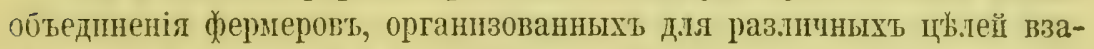
пмопомощи (испттаніе мо.тчнато скота, усовершенствованіе методов'ь (анптаризацін и пропвводства молока и т. д.), но, вслтдствіе своей разрознениості, они безсиььны бы.ти противодуйствовать мо.топнымъ

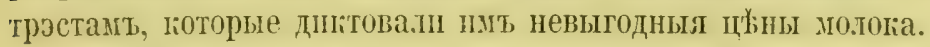

.Тига „Молочно-Фермерспихт, Организацій“" ІІ взлла на сео́я пниціативу ойъединенія всжх бермеровъ дхя организапіп сбыта молока пю болье благопріятнымъ цьнамъ.

Само соб́ої разум'ьетсл, что подобная оранизація могла разсчи-

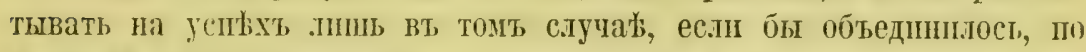

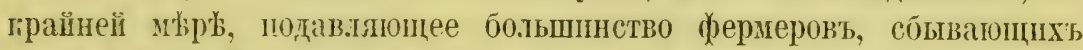

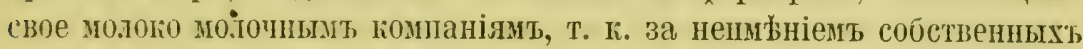
пастерпваціонныхь заводовъ іл другихъ вспомогательныхь средствт распредь.пте.тьнаго аппарата, фермера, объеднненые въ ,лигу“, не могли бы установить неносредственнаго гонтрагта с’ городсним потребителями, а неорганвованная часть фермеровт продолікала бы обс.луживать молочныл компаніп.

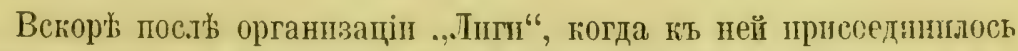
нћсколько тыслч фермеровъ, была объявлена первая (1916 г.) молочная забастовна - отказт продавать молоко па предложеншыхт ус.овіяхъ молочными компаніми, эта забастовка оыла вынграна фермерами. .Јишь ст этого мохента всъ форериера почувствовали спи- 
ғамт очевцднуг выгоду организованной борьбы пі быстро стали присоединяться къ Jигу.

Кं 1-му Марту 1919 года насчитывается 996 мыстиыхъ отдылов'ь Лиги, разбросанныхъ въ 6 штатахъ: Коннекпиугъ, Массачусетсъ, Нью-джкерзи, Нью-Іоркъ, Пенсильванія, Вермонтъ. Въ нее входитъ 65.512 членовъ съ 744.700 молочными коровамн, что составляетъ $90 \%$ всьхт фермеровт выпеупомянуыхъ ІІтатовь.

Принцины организаціи Лиги сводятся къ сльдующему:- Пред-

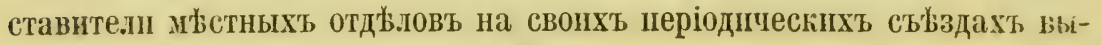
бирають Дирекцію Центральной Јиги:

1. Мысные отдълы Лиги (Локал Кооператив Ассосіәйшон) на свонхь общциъ собранілхъ пзбнрають Исполнительный Комитет: въ лиц'; президента, сегретаря п пассира для постоянныхъ сношеній съ Центра.тьой Јигой и веденія текущихъ д屯ль.

2. Смежные отдылы образують Районный Центрь (Риджионал Iоолератпвь Ассосізйшон) на территоріп части или всего штата.

3. Районные отдъзы объединяются вт Центральную Лигу, пред-

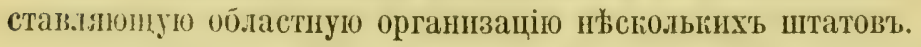

ценгральная Лига пвбирается на областныхъ ежегодныхъ съђз-

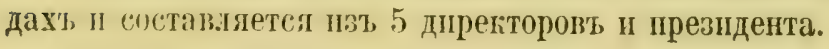

На об̆взанности дирекцін лежить:

1. Пздапіе ежіенеджльнаго журнала.

2. Организація молочныхъ выставокъ.

3. Забота объ улучшеніи молочнаго пронзводства.

4. Организація регулярнхъ понференцій всъхъ членовъ лиги.

5. Снопеніе съ правптельственными и сангтарно-контрольными учрежіденіями.

6. Разработка новыхт проектовъ дылтельности Лиги въ области оборудованія собственныхъ пастершзаціоншыхъ депо.

7. Дирекція ивучаеть положеніе молочнаго рыніа и устанавлваетъ контракты сь молочными фирмами всьхъ мыстечекъ и 
городовъ на поставку опредж.леннаго колпчества молока, по цҺнамъ фиксированнымъ авансомъ на три мысяца. (Расцьнка ведется на 100 фунтовь молока).

Для содержанія .Јигп обраэуется фондт пют отчисленій съ ферровъ въ размљр 1 цента за каждые 100 фулнгвъ проданнаго молока.

.ига является высшимь органомъ пю сбыту мо.лога. Опа лигизована Центральної Государственної в.астью и пюмимо ея ни одинт, ч.ленъ организаціи не можеть продавать молока на сторону. Въ свою очередь, молочныя помпаніп могуть полутать уолого не пнате, гаћъ по періодически устанавливаемымъ цынамь путемъ спеціальныхъ соглашеній съ Лигой.

\section{ОПТОВАЯ ЦБНА НА МОЛОКО, УСТАНОВЛЕННАЯ ЛИГОИ ДЛЯ ГОРОДА НЬЮ-ІОРКА на ФЕВРАЛЬ-МАРТЬ 1919 ГОДА.}

Проетранство транспортировки модога въ миляхт отъ Нью-Іорка
За 1000 фунтовъ молова въ 40 бу. тылочныхт циньовых" банкахт

Мартъ

0ть 100 миль и меньше

3 дол. 72 щ.

3 дол. 49 щ.

Свыше 10 м., но не больше 20 м.

Свыше 20, но не больше 30

Свыше 30 , но не болыше 40

$\begin{array}{lll}3 & , & 70, \\ 3 & , & 69, \\ 3 & , & 68,\end{array}$

3,47,

3,46,

3 , 45,

Кончается эта ска.ла цинь :

Свыmе 500, но не больше $550 \quad 3,22$,

3,05,

Кооперапіоннымъ центромъ этихъ областныхъ лигъ яв.яются ежегодные събзды.

Такимъ образомъ, за 41/2 года феремеры созда.ит моцпуго національную организацію, параливовавшую дъятельность молочныхъ трэcron\%.

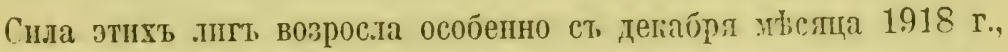
ғогта пми была проведена длительная вабастовка ст необыновенным

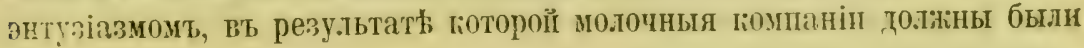


прннять условія Лити и поднять фермєрамъ цйну на холоко за январь мьсяцъ съ 3 долл. 60 центовъ до 4 дол.л. 1 цента за 100 фунтовъ.

Средняя ц'вна на молого за 1917 годъ равня.тась 2 долл. 41 центу (за 100 фунтовъ), а въ 1918 году, б.тагодаря энергичной дъятельности Центральної .Іпгш, ц'на была поднята до 3 долларовъ 1 цента, т.-е. на 60 центовт выше прошлаго года, что составпло џистой прибыли для 60.000 фермеровъ, состоятихъ членамп Нью-Іоркской Лпги, -20.485.206 долларовъ. За 60 вынгранныхъ центовъ со 100 фунтовъ проданнаго молока ферхеры отчис.тя.пі всего лишь одинь пенть въ пользу Лиги. Если и вщредь дуьлтельность фермерскихь лигъ будеть продолжатьсл въ томъ же масштабъ, то въ ближайшіе годы можно ожидать полної ликвндапіи молочныхъ помпаній по всей странь. ${ }^{*}$ )

Уже теперь центральныя лпгп разрабатыватоть планъ оборудованія собственныхъ молочныхъ депо, маслодъльныхъ и сыроваренныхъ заводовъ во веъхъ больпихъ тородахъ п провиндіальныхъ молочнопромышленныхъ центрахъ.

Пронзводство молочных’ продуктовъ собственными средствами позволить фермерамъ утплизировать въ льтнее время весь избытокь непроданнаго молога для пропзводства сыра и масла и внесеть большую планомжрность и экономію въ молочныхъ промышленности и торговль въ Америкъ.

Комитетъ Бостонскої Торговой Палаты въ своемъ обсльдованіи молочнаго дъла въ Штатъ Ныо-Ингландъ (Новая Англія) настойчпво рекомендуеть фермерамъ организовать собственныя молочныя сыроварни и маслодыьные заводы, находя въ этомъ единственның правпльный путь для разрышенія мъстныхъ молочныхъ проблемъ: удешевленія іг улучшенія качества молока.

За послждніе трп тода кооперативныя молочныл депо въ Новон Англіи, оборудованныя въ весьма скромныхъ размърахъ, стонмостью отъ 2.000 до 20.000 долларовъ, приносплг кооперативамъ ежегодно около 100.000 долларовъ тистої прнбылн.

Въ зағлюченіе мы можемъ сказать, тто съ ростомъ кооперативовъ развитіе молочнаго дынла въ Амернкт достигнеть еще больпихъ

*) Вт ноябрғ мъсяц 1919 г. городскимъ самоуправленіемъ г. Нью-Іорва поетановлено прнетупить къ вемедленной разработки плапа муииципадизадін модоңваго снабженія. 
результатовъ въ области не только санитаризаціи и техники молочной промышленности, но эти кооперативы, по примъру Дажскихэ маслодблов' п Калифорнскихъ фруктоводовъ, смогуть выполнить всіо сложную задачу организаціп сбыта и снабженія мологомъ прупнъйшихъ американскихъ городовъ.

Для иллюстраціи того, гағъ молочныя цъзны устанавливаются, мы прпвели выше бюллетень цънт за февраль и марть мысяцы, опублиюованные Лигої для города Нью-Іорка на молоко съ $3 \%$ содержимостью молочнаго жнра, градаціп „В“" 


\section{СНАБЖЕНІЕ МОЛОКОМЪ ГОРОДА НЬЮ-ІОРКА.}

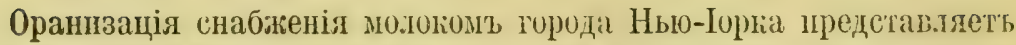

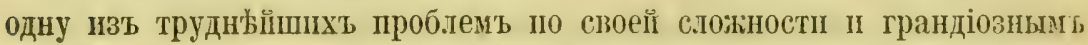
размърамъ количества молока, постав.лемаго ежедневно д.я насе.еніл въ 9.000 .000 человъкъ.

Все снабженіе молокомь гонтролируется тремя крупнип поммерческими компаніями и „Кооперативной .Іигой фермеровь“, ойъединигщей 80.000 фермеровъ.

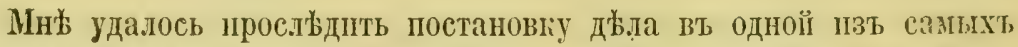
крупныхъ фермъ „Bordens Farm Products Company, Inc.“ въ Hs:t)-

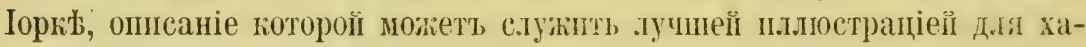
рањтернстиғи организаціи снайженія мологомь, не только города НьюІорка, но и веъхт многольдныхъ центровъ Соединенныхъ ІІтатовт Съверной Амернин.

„Bordens Farm Products Company, Inc." существуетъ съ 50-хъ годовь прошлаго стольтія. Ея основной каниталь составляеть 17.000.

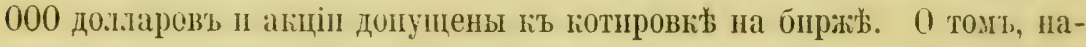
сколько прочно она стонть вь финансовомь отиопеніп, показателем ь яв.яется выдача 6-8\% дивнденда вт теченіе посльднихъ 12 льтт.

Эта фирма спеціа.пвировалась всецыло на посредншеств между пронвводите.емъ-()ермеромь и городсинь потребителемь по поставкж жндгато молока, сметаны иі спиокь. Веђ остальные виды ея дылтельности имыоть вспомогательное значеніе.

\section{ЗАКУПКА МОЛОКА.}

Въ онрестностяхт, города Нъю-Іорка, въ радіус'в 400 мнль, эта фирма оборудовала 250 понцентраціонныхъ станцій, пуда подвозител ежедневио свънее молого қермерами, живущими въ прилегаюцихт қъ қонцентраціоннымъ станцілмт, райопахъ. 
Фермерт, обыкновенно заключаеть контрағть съ фирной на поставку опредъзиннаго количества молога въ тепеніе года, полугода или чаще всего одного мъсяца по точно фикспрованной пьны на 100 фуннтов' мо.тоria.

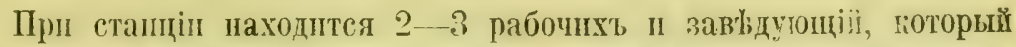

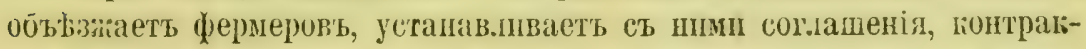
ты на поставіу, расчеты II пр. и регулируеть транспортировіу молога въ соотвътетвіи съ ннетругціями, поступающими изъ главної НьюІоркекой конторы.

Молоко содержится на этихъ станціяхъ въ теченіе $3-6$ часовт н хранится въ обычныхъ цинковыхъ банкахъ.

\section{РАСПРЕДЬЛЕНІЕ МОЛОКА ВЪ КОНЦЕНТРАЦІОННЫХЪ СТАНЦІЯХъ.}

Въ виду того, что качество молока, поступающаго отъ фернеровъ, колеблется въ процентномь содержаніи жира, (отъ $3-4 \%$ ) и требованіе на количество молока пз' Нью-Іорка мыняется почти каждый день, то приходится распредъзять молоко въ зависнмости оть его качества и количества между Нью-Іоркомъ и заводами, Bordens Farm Products Company, которые равбросаны по всему Нью-Іоркскому пттаTy.

Такимъ образомъ, достигается утилизація всьхъ избытковъ молока оть ежедневной продажи въ Нью-Іоркъ или другихъ городах'ь: Нуаркъ, Патерсонћ, Пассейкъ, Исть Оранджъ, Монтклерџ и т. д., которые снабжаются той же компаніей.

\section{ТРАНСПОРТИРОВКА МОЛОКА.}

Всж жельзнодорожныя линіп, подъ вліяніемъ дылтельности сани-

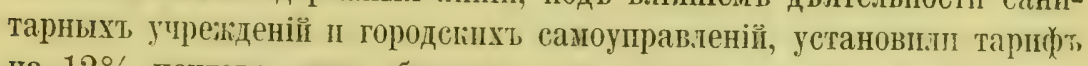
на $12 \%$ центовъ ншке обытнаго для перевозкі молока ил построп.и спеціальные рефрегераторпые вагоны, прикрупляемые кь экспресснымь пожздамт и оборудованиые по типу первоклассныхъ пассажир- 
скихъ вагоновъ. Они вмщаютъ 300 молочныхъ бюдоновъ или 550 лщиковъ съ 12 бутылками каядый. Эти вагоны пмъють вентиляторы и двери съ об̆Њихъ сторонъ, что позволяетъ тегкую и о̆ыструю погрузіу молога. Въ ирышахъ вагона продыланы люги д.л наполненія вагоновъ льдомъ на ледяныхъ станціяхъ льдомъ, которыц помьщаетсл въ особыхъ карманахъ и поддержнваетъ постоянную температуру въ $40^{\circ}$ по Фаренгейту.

Всльдствіе того, что птать Нью-Іоркъ отлпчается нсключительной плотностью населенія (23.000.000 человъьъ), то по всъмъ пригороднымъ жельзнодоржнымъ пиніямь расположена трезвычайно густал сёть станцій, гдж устроены все необходимыя оборудованія для храненія молока, которое поставляется въ Нью-Іоркъ съ невљроятной быстротой и въ какомь угодно количествь.

\section{РАСПРЕДЬЛЕНІЕ МОЛОКА ВЪ ГОР. НЬЮ-ІОРКち.}

До 10-ти часовъ утра необходимое количество молока поступаеть на различныя желъзнодорожныл станціл съ концентраціонныхъ пунк-

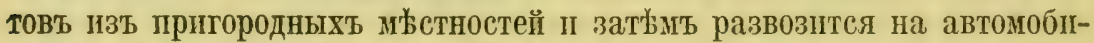
ляхъ, загрытыхъ кузовами, по 7-мп пастернзаціоннымъ заводамъ, прннадлежащимъ той-же фирмъ и расположеннымъ въ различныхъ частяхъ города Нью-Іорка.

Первая операція со свъжпъ молокомъ начтнается съ разгрузки автомобилей. Бидоны съ молокомь поступають на закрытую платформу, гдъ опоражниваются въ открытый кубпческій сосудъ, а затьмт пустыми пропускаются на конвеерахъ черезъ особую машпну, гдъ они обмываются спльной струей горячей воды и пара. Отсюда они движутся непрерывної вереншцеї къ платформ\%, откуда укладываются на ту же трузовые автомобили съ прицйпными тельгами для в03врапенія по ж.-д. линіямъ обратно на гонцентраціонныя станцін.

Дальныйіе продессы пастерпвапіп захолажпванія, разливкп иі храненія молока пропсходятъ аналогитнымъ образомъ, какъ это описано нами въ спеціальныхъ главахъ.

Пронзводптельность указанныхъ семп пастерпзадіонныхъ депо колеблется отъ 25.000 до 75.000 буты.токъ м0.10га, выпускаемыхт па продажу въь сутки. 
Вен операпіоныл помыценія депо содержатся вт тпательной чикстоть.

Полы, сог.ласпо треб́ованію санитарғаго қонтро.л, выстланы це-

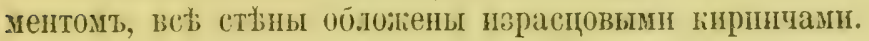

Весь рабочій персоналт, получаетт отт, фирмы спеціальное хол-

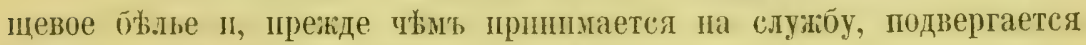
медицнскому освддътельствованію.

0коло $60 \%$ рабочнхъ вт депо состоятт, пвъ женцинъ, зарабатывапщихъ оголо 4 дол. въ день. Завъдующіе раб̆отамп говорилг мнъ, что женщины быстрће п тнательне управ.яптея съ мытьемъ посуды, разливкой и јнағовкой бутылогі.

Прп ғаждояъ депо имйотся э.текричесгая станція, паровые потлы, отдъ.ленія для пропвводства льда, рефрижираторныя помыщенія, вт, которыхъ температура подеришвается въ предылахъ $6^{\circ}-8^{\circ}$ по Фаренгейту.

Фирма содержитъ оголо 1.000 собственныхъ лопадей и столько же фургоновъ для развозюи молога.

На Нью-Іорғъ работаеть 40.000 бернеровъ съ 4.000.000 горовъ *)

Молого поставляется въ, количествђ около 2.000.000 бутылог ежедневно пзъ 7-ми штатовъ **). Это мотого собпраетсл ст 1.200 концентраціонныхъ станцій ІІ подвозится по 11 эіелъзнодорожнымъ линіямъ на разстоянін отъ 50 до 425 миль.

По Ныр-Іоргіу молого развозится вт, 5500 форргопагъ по 127.000 гвартирамъ и учрежденіямъ.

Въ молочную промышленность города Нью-Іорка вложено 25.000. 000 долларовт; оть продажіг молока выручается - 200.000.000 дол.аров'ь ежегодно, изь которыхъ 50\% сәставдяеть выручку фернеровт, остальные поступають молочнымъ томганіямъ - N. H. Parker, City Milk Supply, N. Y. C. I9I7.

*) (Dr. North, Superg. Milk, New York City, 1918.)

**) ("The Dairymen's League News," March.) 


\section{ПРОИЗВОДСТВО СУХОГО МОЛОКА.}

Въ пятндеслтыхъ годахъ XUX-го стольтія нькго г. Грамвалъ въ Англіи пропзвель первый, но бевуспьшный, опыть полученія сухого молока путемь выпарпванія.

Въ 1899 г. В. Б. Гарри пвобрђлт аптарать для пронзводстви сухого молока, и съ этого времени начннаеть развиваться въ широкомъ масштабъ проивводство сухого молока въ Америкъ.

Одна пзъ крупньйтпхъ пестп фпрмъ, оперпруюппхъ въ птатғ Нью-Іоргъ̆, „Merrell Soule Powdered Milk Company“, первая об́орудовала фабрику сухого молока въ 1905 году въ городы Файстевилъ II со времени покупки патентов' на различныя техниескія ус0вершенствованія въ этої промыш.тенності отъ г. Стауффа (вт Позент, Германія) успьла открыть десять новыхъ аналогичныхъ фабрикъ въ штать Нью-Іоргъ: Аркада, Фревсбургъ, Гейсвиль, Ютикћ и Варшавћ; въ штать Пенсильванія: Юніонъ Сити, Ватерфордъ, и въ штатж; Небраска: 0маха,-поднявъ ежедневное пропзводство сухого молога пг всъхъ фабрніахъ съ 2.500 фунтовъ двънадцать люьть тому назадъ до 50.000 фунтовъ, или свыше 125 пудовъ ежедневно-въ 1918 году.

Изъ әтого одного фбакта уже видно, какое быстрое развитіе пріобр`зтаетъ эта столь молодая промышленность въ Амерниь.

Тагіе знатокп молочнаго дйла, пакт т-ръ Тарльзъ Нортъ, нө беят, основанія полагапть, тто въ недалекомъ будущемъ порошко-образное молоко, наряду съ конденспрованнымъ, будеть служнтт предметомт, массоваго экспорта на пностранные рынгі, особенно въ тропическіл II холодныя страны, гдӝ климатпческія условія не благопріятствуютт, молочному хозяйству. Г-нъ 0. Ф. Гицциеръ, директоръ Молочнаги Департамента Эксперпментальної Станціп штата Индіана, въ своей работь сльдующими словани характернзуеть сухое молозо:

„Ивъ всъхт методовт, пропвводства моточнаго порошка-напболье соверпенный практикеть Меррель п Гарп. Онъ заклю- 


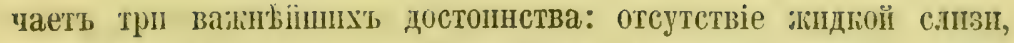
позволяющеї развшаться бактеріямь молонныї зирь остаетсл въ глобу.лрной формъ пі всльдствіе этого быетро и совершенно смишивается съ водої; оорразуеть концентрнрованцую эмульсію, содержащую натуралыный а.эьбумин въ несвертываюцейсл (створажівающейся) формћ, что обезпечпваеть полное раствореніе молочнаго порошка въ воджы“".

Процессъ выпарнванія цъ..тнаго іп тпстаго молока не повреяддаеть его жизненныхъ пл питательныхъ гачествъ.

Молоко въ порошгообразномъ состояніп пмъетъ знатнтельныя препмуества передъ обыгноеннымъ :

1. Въ немъ пріостанавливается развптіе бактерії, пा потому оно вполнъ годно д.ля продолжительнаго храненія.

2. Въ этой форм' его легче всего упаговать, транспортировать и содержать для продажи.

3. Это напболье дешевый п удобный молочный препарать для печеніл, фабрпкаціп конфектъ, мороженнаго и для разнаго употребленія въ гулннарномъ дъъ.ъ.

4. Онъ получпль шпрокое распространеніе въ кухняхъ ресторановъ, клубовъ, пароходовъ и пр., всльдствіе легкости полученія молока, үпотребляемаго для прнготовленія самых' разнообразныхъ блидъ, какъ-то: соусовт, пудннговъ, шарлоть и пр.

Его транспортпровга въ семь разъ депевте жптпаго молога, заключающаго семь осьмыхъ воды.

Какъ пзвьстно, въ литніе мисяпы у фермеровъ получается больпой пзбытокъ молока, которы они вынуждены сбывать на рынокъ (для пропвводства сыра п масла) по крайне нивкимъ цъннамъ.

Теперь же сткрывается возможность пспользовать этоть пзбытокъ д.ля фабрикацін молочнаго порошка по болье благопріятнымъ цънамь

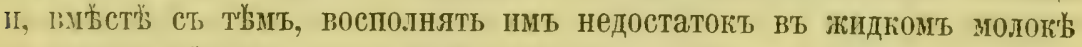
в’ь вимніе итсяды, когда удой коровъ значительно сокрапается.

Пропзводство молочнаго порошка на каждой фабрнкъ состав.ляеть

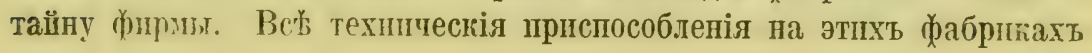


ғах'ь патентованы іп всякое повапетвованіе пми иағавывается суровыми карами.

Мы можемъ представить здъсь лишь впечат.тынія оть осмотра фаб̆рики въ Аркады, принадлежащей Компаніи „Меррель Соуль Паудерь Милкь".

Здъсь употребляетел екедневно до 300.000 кварть жіпдіаго молока; форерера привякять молого въ цинковыхъ банкахъ. Спеціальные инспектора отвупоривають эти б́анин и, посль' предварительной пнспекцін, сливають молоко въ большіе цилиндрическіе пріемникі, откуда оно поступаеть по трубкамь въ сепараторы. Здъсь отдь.леятся молочный жиръ, готорый пастерпвуется, захолаживается и приготовляетея длх оптовой ип розниной продажіг. Остаюцееся снятое молоко поступаеть въ свою очередь въ пастеризацію. За-

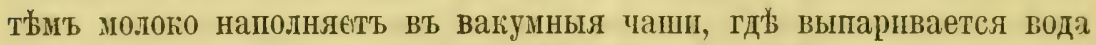
путемъ конденсаціи въ темгературж, сохраняющей въ неповрежденномъ видж альбуминь и не вліяющей на остальные живые элехгенты молока.

Посль этого наступаеть, важньйшая, нанболье продолжтельная часть процесса.

Конденсированная, тязуая масса протягивается черезъ тончайшія отверстія въ металическомь дискь, установленномт въ вагумномъ барабанъ. Остатки жндкой слизи въ это время выпарнваются горячимь воздухом'ь, а остальная высохшая тасть молока высыпается на дно камеры в'ь видъ бълосньжной групы, чрезвычайно похожеї на муюу, составляющей окончательный продукть молочнаго порошка.

Какъ уже было замъчено, вытлжка тягучей массы черезъ мъдные диски не измьнеть химческой основы молочной ғомпозі.

Посльвдняя операція занлючается въ медленномъ охлажденіп молочной пудрш, въ цйляхъ предохраненія ел отъ возмоннаго окисленія.

Молочная пудра поступаетъ вт проданіу въ 50, 10 і 5 фоунтовыхъ пакетахъ, ящикахъ или небольшихъ боченкахъ.

Молочная пудра поступаеть на рынокъ въ видъ̆ разнообразныхъ молочныхъ продуктовъ, въ зависијости отъ промышленнаго назначенія. 
1. Молочная пудра оть снятаго молока "Powdered Skimmed Milk" пдеть иа приготовленіе ппслаго молока (Ботер Милі) в'ь паетерпзаціонныя городскія депо для пропвводства обытнаго столоваго молока, сливокъ и прочее.

2. Пудровое ц’в.ьное молоко (Подред 0.г Мил:) вырабатываетея пвъ натуральнаго молока, содержацее $3 \%$ молочнаго жира. Въ порошко-образномъ состояніи оно заключаетъ отъ $25 \%$ до $271 / 2 \%$ молочнаго жира.

0но успьшно замънлеть обычне конденспрованное молоко.

3. Пудровыя сливьн - "Cream Powders"

Вырабатываются изъ натуральнаго молока съ содержимостьо $9 \%$ молочнаго жира. Пудровыя сливки вырабатываются въ нъсколькихъ сортахъ, въ которыхъ продентъ молочнаго жира варыиуется оть 50 до 72.

Возстановленіе молога или другихъ молочныхъ продуктовъ пзъ вышеуказанныхъ молочныхъ препаратовъ - производится въ домашнемъ обиходь путемъ разведенія пуды водой, голпчество которой балансируется въ зависпмости отъ назначенія приготовляемаго молока.

Для полученія жидкаго молока, чаще всего беруть сльдующую пропорцію: на 1100 фунтовъ воды - 91/4 - 91/2 молочнаго порошка.

Если на каждые 100 фунтовъ воды полагается 9.5 фун. молочнаго порошка, то д.ля полученія 1.720 фун. полока потребуется 163 фунта молочнаго порошка и 1.577 фунтовъ воды.

Молочный поропоєъ обычно растворяется сльдующимъ способомъ:

Требуемое количество воды наливается въ котелъ, подогржваемый на угляхъ, газъ или сжатымъ паромг. Температура воды поднимается до $90^{\circ}-100^{\circ}$ Фаренгейтъ, зать̌ьь подсыпается и размьшивается соотвнтствующее колпчество молочнаго порошка и, когда посльдній окончате.льно растворится,--температуру сльдуетъ поднять быстро до $145^{\circ}$, въ которой уже разведенное молоко выдержнвается 30 минуть, посль чего она быстро опусгается до $45^{\circ}$ и тогда мы получаемь готовый продукть для употребленія. 
Особенное широге распространеніе получиль молочный порощонь

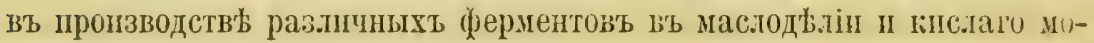
лога.

Намъ не пзвъстно, гакт да.теко пойдетъ развитіе производства молочнаго порошка въ будущемъ, но пмъюціеся фанты позволяють ваключить, что торгово-промышленное значеніе сухого молола, въ условіяхъ Американской нидустрін чрезвычайюо грунно и со временент вайметь выдающееся м'ьсто в’ь ряду другихъ молочныхъ продуктовъ. 


\section{ПРИЛОЖЕНІЕ I. БИБЛІОГРАФІЯ}

HaGGard, "Rural Denmark and its Lessons," I9I3.

Hinman, "Butterfat Variation in Indianopolis Milk," Hoard's Dairyman, vol. 48, Aug. I, 1913 .

PECK, "The Problem of Obtaining Milk for large cities and the Equalization between Supply and Demand," Proc. 6th Annual Convention of the International Milk Dealer's Assn., pp. 75-79, I9I3.

VAN Slyke, "Modern Methods of Testing Milk Products," 1913.

Savage, "Milk and the Public Health," 1912.

Mrciels, "Market Dairying and Milk Products, I9I2.

Rosenau, "The Milk Question," rgl2.

Marshall, "Microbiology," I9I2.

WARD, "Pure Milk and the Public Health," Igog.

Drlion, "The Milk Problem," Igr6.

KELLY, "The Need for Medical Inspection of Employees who are Engaged in the Production and Handling of Milk," 4th Annual Report of the International Assn. of Dairy and Milk Inspectors, pp. 8I-86, October, I9I5.

Campbell, "Medical Inspection of Certified Dairies," Ill. Med. Jour., vol. 28, No. 2, pp. 90-93, August, 1915.

Bafrlman, "Milk Clarifiers," Am. Jour. Public Health, vol. 6, No. 8, p. 854 , I9I6.

Hin Kelman, "Micro-Organic Weight," 1915, Illionis Med. Jour., vol. 29, No. 3, p. 202, 1916.

McClintock, "Further Investigation upon Clarification of Milk," The Milk Trade Journal, September, I916, p. 64. 
HAMMER, "Studies on the Clarification of Milk," Res. Bull. 28, Exp. Sta., Iowa State College of Ag. and Mech. Arts, I9ı6.

HaRding \& Rogers, "The Efficiency of a Continuous Pasteurizer at Different Temperatures," Bull. I72, N. Y. Ag. Expt. Sta., 1899.

Sammis \& BRUhn, "The Manufacture of Cheese of the Cheddar Type from Pasteurized Milk," Bull. 165, Bureau Animal Industry, U. S. Dept. Ag., I9r3.

Montaneer, Gaessler, Cooper \& Hammer, "The Pasteurization of Cream for Butter Making," Bull. 156, Iowa State College Ag. Expt. Sta., I9I4.

PEASE, "The Sanitary Significance of Bacteria in Milk," Proc. 6th Annual Convention of the International Milk Dealers' As'n, I9I3.

Straus, L. G., "Disease in Milk-The Remedy Pasteurization," I9I3.

RupP, "Chemical Changes Produced in Cow's Milk by Pasteurization," Bull. I66, Bureau Animal Industry, U. S. Dept. Ag., April, I9I3.

Dosch, "The Pasteurized Milk Fraud," Pearson's Magazine, Decem-. ber, 1910.

Roтch, "The Pasteurization of Milk for Public Sale," Amer. Jour. Public Hygiene, vol. I7, No. 2, May, 1907.

DeSchweinitz, "The Pasteurization and Sterilization of Milk," Yearbook U. S. Dept. Ag., I894.

Ayres \& Johnson, "The Bacteriology of Commercially Pasteurized and Raw Market Milk," Bull. I26 Bureau Animal Industry, U. S. Dept. Ag.

Rosenau, "Pasteurization, Its Advantages and Disadvantages," Circ. I53, Bureau Animal Industry, U. S. Dept. Ag., I9Io.

WeLd, "George M., Oyster Jr., Baby Milk Philanthropy," IgI2.

Collaway, "The Pasteurization of Milk," The Trade Milk Journal, vol. 3 , Nos. 8 and 9, October and December, I915.

Hansen \& Parker, "Typhoid Fever in Rockford, Ill.," Jour. Infect. Diseases, vol. I6, No. I, p. 20, January, I9I5. 
Smitir, Theobald, "The Thermal Death Point of Tubercle Bacilli in Milk and Some OtherFluids," Jour. Exper. Med., vol. 4, pp. 2r7233,1899 .

Russell \& Hastings, "Thermal Death Point of Tubercle Bacilli Under Commercial Conditions," Univ. Wis. Ag. Expt. Sta., I7th Annual Report, I900.

Rosenau, "The Thermal Death Points of Pathogenic Micro-organisms in Milk," Hygienic Lab. Bull. 42, Public Health and Marine Hospital Service, January, 1908.

Lumsden, "The Milk Supply of iCties in Relation to the Epidemiology of Typhoid Fever," Bull. 4I, Public Health and Marine Hospital Service.

Boldan, "Typhoid Fever in New York City," Department of Health of New York City, Monograph Series, No. 3, August, 1912.

Geiger \& Kelly, "Pasteurization of Milk Supplies as a Protection Against Typhoid Fever," Jour. A.M.A., Vol. 66, No. 3, Jan. 22, I9ı.

Hess, "Infantile Scurvey; III. Its Influence on Growth (length and weight)," Am. Jour. of Diseases of Children, vol. 12, pp. I52-165. August, 19r6.

Schroer \& Rosenau, "Tests of the Efficiency of Pasteurization under Practical Conditions," Hour Med. Res., vol. 26, No. I, April, I9I2.

Russeli, "The Year's Progress of the Experiment Station," Bull. 250, Univ. Wis. Ag. Expt. Sta., April, I9I5.

Sturgis, "The Role of Dairy Inspection in Safeguarding a City's Milk Supply," Department of Health of the City of New York, Reprint Series, No. 30, June, 19I5.

Kilbourne, "Pasteurization of Milk with Suggestions as to Methods and Apparatus to be Employed," Am. Jour. Public Health, vol. 2, No. 8, pp. 626-634, August, 1912.

Ayres, "The Pasteurization of Milk," Circ. r84, Bureau Animal Industry, U. S. Dept. Ag., I9I2. 
Ayres, "Pasteurizing Milk in Bottles and Bottling Hot Milk Pasteurized in Bulk," Bull. 240, U. S. Dept. Ag., July I915.

Ayres, Bowen \& Johnson, "Cooling Hot-bottles Pasteurized Milk by Forced Air," Bull. 420, U. S. Dept. Ag., October 27, 1916.

Castle, "The Chemistry of Milk," Hygienic Lab., Bull. 56, pp. 315$425,1909$.

Hunziker, "Pasteurization of Market Milk," The Milk Trade Jour., pp. 36 and 44, June, I9I6.

Kilbourne, "What Causes Contribute to the Loss of the Cream Line in Pausterized Milk in Bottles," Department of Health of New York City, Reprint Series, No. 27, April, I915; Jour. A. M. A., vol. 63 , No. I, p. 50, July 4, 1915, "Decision Upholding Automatic Temperature Control."

Ayres \& Johnson, "A Study of the Bacteria that Survive Pasteurization," Bull. I6I, Bureau Animal Industry, U. S. Dept. Ag., I9I3.

Ayres \& Jornson, "Ability of Colon Bacilli to Survive Pasteurization," Jour. Ag. Res., vol. 3, No. 5, pp. 40I-4I6, Feb. I5, J9I5.

Ayres \& JoIrnson, "Ability of Streptococci to Survive Pasteurization," Jour. Ag. Res., vol. 2, No. 4, pp. 32I-330, I9I4.

Thom \& Ayres, "Effect of Pasteurization on Mould Spores," Jour. Ag. Res., vol. 6, No. 4, 1916.

Davis, "Bacteriologic Study of Streptococci in Milk in Relation tu Epidemic Sore Throat," Jour. A.M.A., vol. 58, No. 24, pp. 18521854, June I5, I9I2.

Hamburger, "The Baltimore Epidemic of Septic Sore Throat and its Relation to the Milk Supply," Bull. Johns Hopkins Hospital, vol, 24. No. 263, pp. I-II, I9I3.

NoRTH, "Pasteurization of Milk in the Bottle on a Commercial Scale," Med. Rec., July I5, I9II.

CARTER, "Pasteurization of Milk in the Sealed and Final Package," Jour. Am. Public Health Assn., vol. I, No. 9, pp. 60.4-668, Sep-. tember, I9rI. 
Hammer, "The Pasteurization of Milk in the Final Package," Bull. 154, Iowa State College Ag. Expt. Sta., November, 19I4.

Report of the Board of Commissioners of Agriculture and Forestry of the Territory of Hawaii for the Biennium Ending Dec. 3I, 1912, "Milk Purifying by Electricity," pp. 185-187.

LEwIS, "Destruction of Bacteria in Milk by Electricity," Jour. Board of Ag., vol. 22, No. 12, pp. 1229-1239, 1916.

FORD \& PRYOR, "Observations Upon the Bacteria in Milk Heated to Various Temperatures," Bull. John Hopkins Hospital, vol. 25, No. 283, pp. 270-278, September, I9I4.

Pryor, "On the Presence of Spore-bearing Bacteria in Washington Market Milk," Bull. John Hopkins Hospital, vol. 25, No. 283, pp. 276-278, September, I9I4.

LAWrence \& Ford, "Studies on Aerobic Spore-bearing Non-pathogenic Bacteria," Part I, Spore-bearing Bacteria in Milk, Jour. of Bacteriology, vol. I, No. 3, pp. 373-417, 1916.

Brown, H. R., "A Study of the Spore-bearing Basteria in Market Milk," 4Ist Annual Report Massachusetts Board of Health, pp. $632-667$.

Shippen, "Common Organisms in Heated Milk-Their Relation to Their Reactions," Bull. Johns Hopkins Hospital, vol. 26, No. 293 , July, I9I 5 .

Report of Committee on City Milk Plant Inspection of International Association of Dairy and Milk Inspectors, The Creamery and Milk Plant Monthly, vol. 4, Nos. 3 and I5, P. I7.

"Valid Regulations of the Sale of Milk," Jour. A.M.A., vol. 63, No. I, p. 54, 1914.

Axres \& JoHnson, "The Destruction of Bacteria in Milk by Ultraviolet Rays," Wash. Acad. of Sci., vol. 3, No. 5, pp. I6o-I64, March, 19I5.

Houghton \& Davis, "A Study of the Germicidal Action of the Ultraviolet Rays," Am. Jour. Public Health, vol. 4, No. 3, pp. 224-240, March, I9I4. 
Ayres, "The Present Status of the Pasteurization of Milk," Bull. 342, U. S. Dept. Ag., Jan. 8, I9I6.

Morris, "Shipment of Milk in Glass Jars," Jour. Franklin Institute, vol. I09, No. 649, Jan., r880.

Dairy Division, Bureau Animal Industry, U. S. Dept. Ag. Milk Plant, Letters $\mathrm{I}-27$.

Doane, "The Disinfectant Properties of Washing Powders," Bull. 7y, Md. Ag. Expt. Sta., January, I902.

Whittaker \& Mohler, "The Sterilization of Milk Bottles with Calcium Hypochlorite," Am. Jour. Public Health, vol. 2, No. 4, pp. 282-287, April, I9I2.

Bowen, "The Application of Refrigeration to the Handling of Milk," Bull. 98, U. S. Dept Ag.

Ayres, "Pasteurization," Bull. 342, U. S. Dept. Ag., January, I9i6.

Williams, "Use of Ice and Other Means of Preserving Food in Homes," Scientific American Supplement, No. I,983, Jan. 3, I9I I.

Bowen, "The Utilization of Exhaust Steam for Heating Boiler Feed Water and Wash Water in Milk Plants, Creamieries and Dairies," Circ. 209, Bureau Animal Industry, U. S. Dept. Ag., I9I3.

WAY, "A Bacteriologic Comparison of Milk Served in Bottles and by the Dip Method," The Cleveland Med. Jour., vol. 6, No. 4, pp. I47-I54, April.

Sender \& Thompson, "Notes on the Cost of Motor Trucking," Vehicle Res., Bull. 2, Elect. Eng. Dept. Mass. Inst. Tech., I9I2.

THomson, "Relative Fields of Horse, Electric and Gasolene Trucks," Vehicle Res., Bull. 4, Elect. Eng. Dept. Mass. Inst. Tech., Aug., I9I4.

Wrlliams, "The Economic Problems of Milk Distribution in their Relation to Public Health," Trans. I5th International Congress of Hygienic and Demography, I9I2.

Williams, "The Problem of Distribution," Proc. Am. Assn. Med. Milk Commissions, 6th, 7th and Sth Annual Conference, pp. 94II8, I9I5. 
Hood, H. P. and Sons, "Cost of Delivering a Quart of Milk to the Consumer," Hoard's Dairyman, vol. 43, No. 25, p. 859, June 19, 1912.

Kelly, "To Start in the Retail Milk Business," Hoard's Dairyman, vol. 13, p. 553, 1916.

Boston Chamber of Commerce, "Investigation and Analysis of the Production, Transportation, Inspection and Distribution of Milk and Cream in New England," July 1915.

Erf, "Disposal of Dairy and Farm Sewage and Water Supply, Bull. 143, Kan. Ag. College Expt. Sta., February, 1907.

Farrington \& Davis, “The Disposal of Creamery Sewage,” Bull. 245, Univ. Wis. Ag. Expt. Sta., February, 1915.

State Board of Health of Wisconsin, "Purification of Creamery Waste,” 1913.

\section{ФЕРМЕРСКІЕ КООПЕРАТИВЫ ПО СБЫТУ МОЛОКА ВЪ АМЕРИКБ.}

Associated Dairymen of California, Inc.

Sec. S. N. Ayres, 213 Calif. Fruit Bldg., Sacramento, Cal.

California Milk Producers' Association,

1505 S. Main St., Los Angeles, Cal., Sec. S. N. Ayres.

Associated Milk Producers,

San Francisco, Cal.

Northern California Milk Producers' Association,

Sacramento, Cal. 
San Joan Valley Milk Producers' Association, Fresno, Cal.

Colorado Milk Producers' Association, 625 Charles Bldg., Denver, Colo.

Connecticut Milk Producers' Association, 450 Asylum St., Hartford, Conn.

Southern Illinois Milk Producers' Association,

Carlyle, Ill., c/o M. E. Baum.

Milk Producers' Association,

29 S. La Salle St., Chicago, Ill., Sec. W. J. Kittle.

Iowa Dairy Marketing Association, Inc.,

Des Moines, Ia., c/o J. V. Lingenfelter.

Kentucky Milk Producers' Co-operative Association,

1606 Inter-Southern Bldg., Lousville, Ky.,

c/o Philip Weissinger, Pres., Shelbyville, $\mathrm{K}$ v

Warner Long, Secy, Finchville, Ky.

Lousiana Dairymen's Association,

c/o I. S. West, Baton Rouge, La.

New England Milk Producers' Association,

26 Broad St., Boston, Mass., Sec. Richard Pattee.

Michigan Milk Producers' Association,

c/o R. C. Reed, Howell, Mich.

Twin City Milk Producers' Association,

2218 University Ave., Minnesota Transfer, St. Paul, Minn.

Queen City Milk Producers' Association,

Greenwood Bldg., Cincinnati, Ohio.

Ohio Milk Producers' Association,

H. W. Ingersoll, Elyria, Ohio.

Dairymen's Co-operative Association, c/o F. H. Shaw, Jefferson, Ohio.

Pittsburgh Association,

J. W. Wase, Meadville, Pa. 
Central Ohio Milk Producers, c/o Louis Frye, Linden Heights, Ohio.

Dairymen's Association,

Astoria, Ore.

Oregon Dairymen's League,

409 Corbett Bldg., Portland, Ore.

Tri-States Dairymen's Association,

Pres., W. J. Wilson, Imperial, Pa.

Interstate Milk Producers' Association, 722 Head Bldg., Philadelphia, Pa.

United Diary Assn, of Washington, c/o J. A. Scollard, Chehalis, Washington.

Inland Empire Diary Producers' Association, Mgr. A. A. Newberry, Spokane, Wash.

Milwaukee Milk and Cream Shippers Association, 1422 First Nat. Bank Bldg., Milwaukee, Wis.

Maryland and Virginia Milk Producers' Association, Sec. G. L. Gardiner, Germantown, Md.

National Milk Producers' Federation,

Pres. Milo D. Campbell, Coldwater, Mich.

Sec. Chas. A. Lyman, 6 5 Woodward Bldg., Wash., D. C.

Federation of Jewish Farmers of America,

157 East Broadway, New York, N. Y.

Central California Milk Producers' Association, Oakland, Cal. 


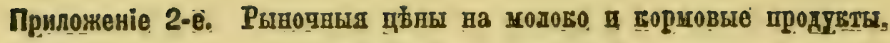

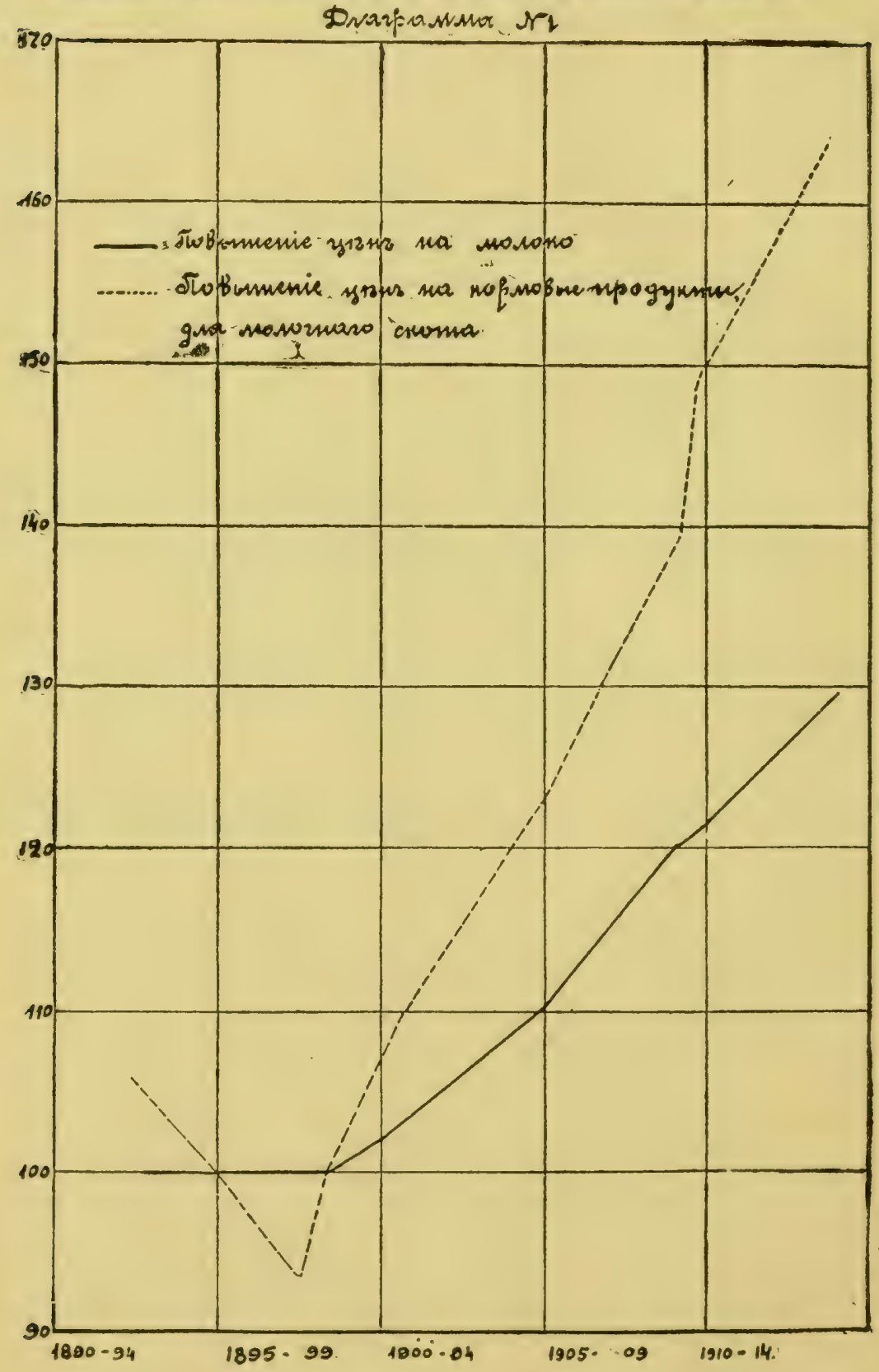


buarperunsua ira

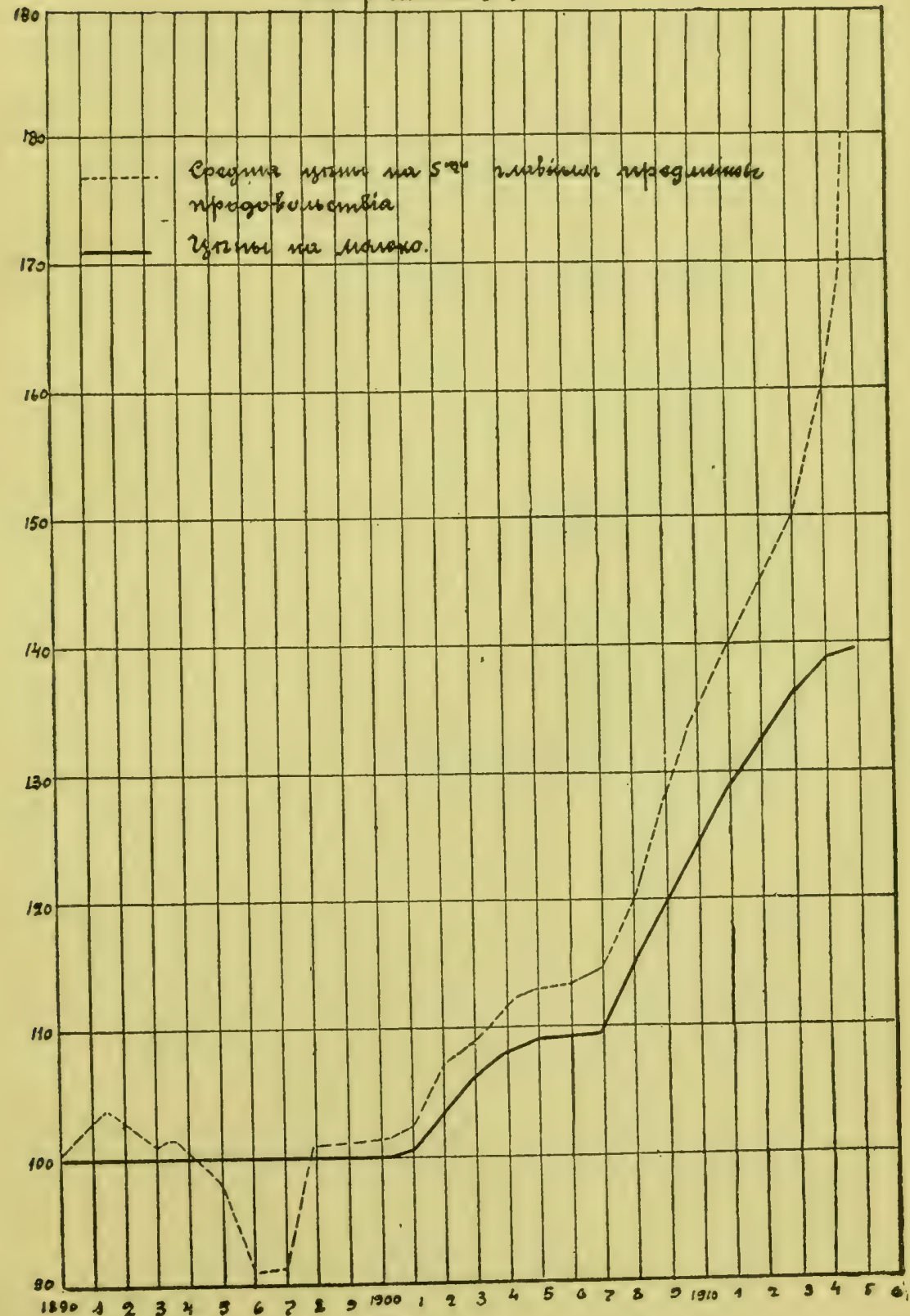





\section{ГОТОВЯТСЯ КЪ ПЕЧАТИ:}

Свнноводство.

Промышлениое шлодоводство.

Расщстка лйсныхт іл каменистыхь почвъ прп помощи взрывча тыхт веществ'b.

образцовал амернканскал ферма - домъ, служов, колодезь с вьтряком'ь и водошроводомъ и пр.

Выборь и оцынка амсрнканспихт сельско-ховяйственныхъ машин" Кооперативный элеваторъ.

Искусственное охлажденіе.

Серія книгъ, изданныхъ международнымъ книгоиздательствомъ: IIO АNЕРИІАНСКИМЬ ИСТОЧНИКАМ'Ь:

0сновы зсмледь̆лія (въ переплеть) ..........\$3.00

Культура лука .................... 40

Искусственное удорреніе ................. 40

Инж. М. Г. КОРСУНСКАГО:

Силосы $\ldots \ldots \ldots \ldots \ldots \ldots \ldots \ldots \ldots \ldots \ldots \ldots \ldots$

Ч. Л. ЛЬЮИСА.

Крушноплодная брусника $\ldots \ldots \ldots \ldots \ldots \ldots \ldots \ldots \ldots$

C. В. ГЕИМАНА:

Техника приготовленія сгущеннаго и сухого молока ... 1.00

Молочное дъљо в’ъ Соединенныхъ Штатахъ ....... 1.00

Проф. Н. А. БОРОДИНА:

Әкономпескія основы сельскаго ховяінтва ........ 50

Естесствознаніе вт прнложепіи къ жизни ........ 50

Способы храненія и затотовки рыоы и ел продуктовъ .... 50

Инเк.-Агр. А. И. ГЛИНЧИКОВА:

Aмериханкіе плуги $\ldots \ldots \ldots \ldots \ldots \ldots \ldots \ldots \ldots \ldots$ 1.00 


\section{АЛЬБОМЪ:}

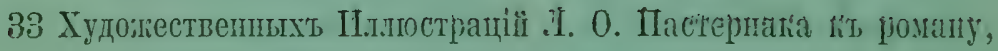

Л. Н. Толстого.

B о с иесен і с

$50 \mathrm{c}$.

International Book Publishing Company

5 Beekman Street

NEW YORK, N. Y,

Teleph. Corlándt 2948 




LIBRARY OF CONGRESS

$$
00028591561
$$

